\title{
nordon
}

Nordic Council of Ministers

\section{Nordic experience of fisheries management}

Seen in relation to the reform of the EU Common Fisheries Policy 




\section{Nordic experience of fisheries management}

Seen in relation to the reform of the EU Common Fisheries Policy

Søren Eliasen and Sten Sverdrup-Jensen Aalborg University Petter Holm and Jahn Petter Johnsen, University of Tromsö 


\section{Nordic experience of fisheries management}

Seen in relation to the reform of the EU Common Fisheries Policy

TemaNordTemaNord 2009:579

(C) Nordic Council of Ministers, Copenhagen 2009

ISBN 978-92-893-1952-2

Print: Kailow Expres A/S

Cover: Publication Unit, NCM

Layout: Publication Unit, NCM

Photos: Cover: Photodisc; s. 13: BeeLine; s. 14: Nikolaj Bock/norden.org; s. 19: Karin Beate

Nøsterud; s. 20: Island: Nikolaj Bock/norden.org; s. 40: BeeLine; s. 56: BeeLine 73: Karin Beate

Nøsterud; ; s. 74 s. Photodisc s. 80: Photodisc

Copies: 230

Printed on environmentally friendly paper

This publication can be ordered on www.norden.org/order. Other Nordic publications are available at www.norden.org/publications

Printed in Denmark

Nordic Council of Ministers

Store Strandstræde 18

DK-1255 Copenhagen K

Phone (+45) 33960200

Fax (+45) 33960202

\section{Nordic Council}

Store Strandstræde 18

DK-1255 Copenhagen K

Phone (+45) 33960400

Fax (+45) 33111870

www.norden.org

\section{Nordic co-operation}

Nordic experience of fisheries managementNordic experience of fisheries managementNordic cooperation is one of the world's most extensive forms of regional collaboration, involving Denmark, Finland, Iceland, Norway, Sweden, and three autonomous areas: the Faroe Islands, Greenland, and Åland.

Nordic cooperation has firm traditions in politics, the economy, and culture. It plays an important role in European and international collaboration, and aims at creating a strong Nordic community in a strong Europe.

Nordic cooperation seeks to safeguard Nordic and regional interests and principles in the global community. Common Nordic values help the region solidify its position as one of the world's most innovative and competitive. 






\section{Nordic experience of fisheries management}

Seen in relation to the reform of the EU Common Fisheries Policy

Søren Eliasen and Sten Sverdrup-Jensen Aalborg University Petter Holm and Jahn Petter Johnsen, University of Tromsö 


\section{Nordic experience of fisheries management}

Seen in relation to the reform of the EU Common Fisheries Policy

TemaNordTemaNord 2009:579

(C) Nordic Council of Ministers, Copenhagen 2009

ISBN 978-92-893-1952-2

Print: Kailow Expres A/S

Cover: Publication Unit, NCM

Layout: Publication Unit, NCM

Photos: Cover: Photodisc; s. 13: BeeLine; s. 14: Nikolaj Bock/norden.org; s. 19: Karin Beate

Nøsterud; s. 20: Island: Nikolaj Bock/norden.org; s. 40: BeeLine; s. 56: BeeLine 73: Karin Beate

Nøsterud; ; s. 74 s. Photodisc s. 80: Photodisc

Copies: 230

Printed on environmentally friendly paper

This publication can be ordered on www.norden.org/order. Other Nordic publications are available at www.norden.org/publications

Printed in Denmark

Nordic Council of Ministers

Store Strandstræde 18

DK-1255 Copenhagen K

Phone (+45) 33960200

Fax (+45) 33960202

\section{Nordic Council}

Store Strandstræde 18

DK-1255 Copenhagen K

Phone (+45) 33960400

Fax (+45) 33111870

www.norden.org

\section{Nordic co-operation}

Nordic experience of fisheries managementNordic experience of fisheries managementNordic cooperation is one of the world's most extensive forms of regional collaboration, involving Denmark, Finland, Iceland, Norway, Sweden, and three autonomous areas: the Faroe Islands, Greenland, and Åland.

Nordic cooperation has firm traditions in politics, the economy, and culture. It plays an important role in European and international collaboration, and aims at creating a strong Nordic community in a strong Europe.

Nordic cooperation seeks to safeguard Nordic and regional interests and principles in the global community. Common Nordic values help the region solidify its position as one of the world's most innovative and competitive. 


\section{Content}

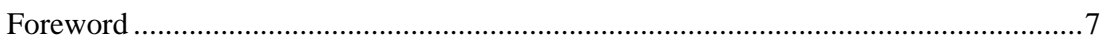

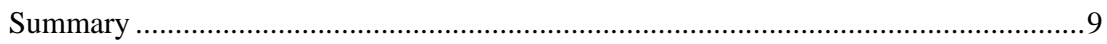

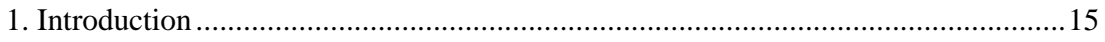

2. Nordic experience of rights-based management....................................................21

2.1 The Green Paper on rights-based management .................................................22

2.2 Rights-based management in the EU ...............................................................2

2.3 Rights-based management in the Nordic countries ............................................24

2.4 Lessons learned from the Nordic countries .......................................................37

3. Nordic experience of co-management .................................................................... 41

3.1 The Green Paper on co-management ..............................................................4

3.2 Co-management in the EU ..........................................................................4

3.3 Co-management in the Nordic countries ........................................................4

3.4 Lessons learned from the Nordic countries .......................................................53

4. Nordic experience of reduction of discards .........................................................57

4.1 The Green Paper on discard ………………………....................................57

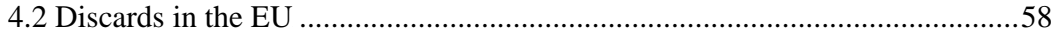

4.3 Reduction of discards in the Nordic countries..................................................59

4.4 Lessons learned from the Nordic countries ......................................................70

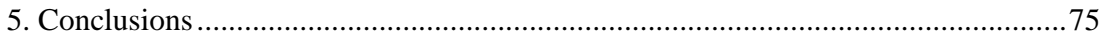

5.1 Rights-based management...............................................................................

5.2 Co-management …………………………………………………………....77

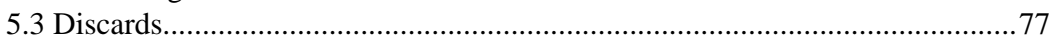

5.4 Linking RBM, co-management and discard policies.........................................78

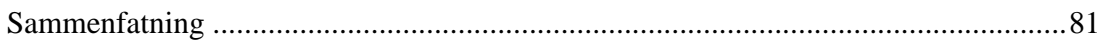




\section{List of Acronyms}

\begin{tabular}{ll}
\hline ACFA & Advisory Committee on Fisheries and Aquaculture \\
CFL & Central Association of Fishers in the Limfjord, Denmark \\
CFP & Common Fisheries Policy \\
EEZ & Exclusive Economic Zones \\
FME & Blue Mussel Association, Denmark \\
GDP & Gross Domestic Product \\
GT & Gross Tonnage \\
GRT & Gross Register Tonnage \\
ITE & Individual Transferable Effort \\
ITQ & Individual Transferable Quota \\
IUU & Illegal, Unregulated and Unreported \\
IVQ & Individual Vessel Quota \\
MCS & Monitoring, Control and Surveillance \\
MSY & Maximum Sustainable Yield \\
NFA & Norwegian Fishermen's Association \\
PO & Producer Organisation \\
RAC & Regional Advisory Council \\
RBM & Rights-Based Management \\
SBF & Swedish Board of Fisheries \\
SFR & Swedish Fishermen's Federation \\
TAC & Total Allowable Catch \\
VMS & Vessel Monitoring System \\
VTQ & Vessel Transferable Quota \\
WWF & World Wide Fund for Nature \\
\hline
\end{tabular}




\section{Foreword}

The Nordic countries have developed seven distinct types of fisheries management. Unlike the West Nordic countries (Greenland, Iceland, the Faroe Islands and Norway), which are not members of the European Union, Denmark, Sweden and Finland are subject to the EU's Common Fisheries Policy.

The seven systems operate in societies that, historically and socially, are characterised by a close sense of affinity and shared values. However, these systems operate under conditions that differ significantly from nation to nation, especially in terms of the countries' economic dependence on fishery resources, their socio-cultural approaches to fisheries, and their marine eco-systems. As a result of these factors, the Nordic countries have relatively diverse systems of fisheries management.

International evaluations of global fisheries management take place at regular intervals. These are conducted by different organisations and employ different criteria. All of these evaluations have ranked the Nordic systems, especially the West Nordic ones, among the best in the world. Nordic diversity i Fisheries Mangement has therefore proven successful at an international level. The Nordic Region is home to many highly sustainable solutions.

The report in your hand is part of the Nordic Council of Ministers' contribution to the debate about reform of the EU Common Fisheries Policy (CFP). The Commission's Green Paper on the CFP, which was published in spring 2009, posed many relevant questions about future fisheries policy and stressed the need for a wide-ranging and fundamental debate on the current situation. The whole basis of EU fisheries policy is up for discussion, and the Nordic Council of Ministers has decided to make an active contribution to that debate. 
This report should be seen in that context. A group of researchers has studied Nordic experiences of, and solutions to, the problems associated with fisheries management. Hopefully, their findings will help inform the European debate. We have chosen to focus our contributions on the following key themes:

- Right-based management

- Co-management

- Discard

We hope that the report will lead to constructive debates in a number of forums in which reform of the CFP is on the agenda. We would also like to encourage representatives of the Nordic fisheries systems to join the debate on reform of the CFP and pass on relevant experiences.

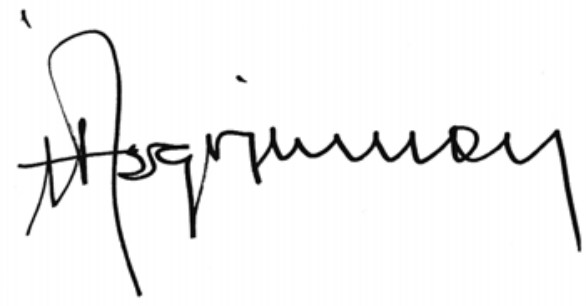

Halldór Ásgrímsson

Secretary General 


\section{Summary}

The purpose of this note is to bring Nordic experience into the discussion of the reform of the Common Fisheries Policy. The discussion takes as its point of departure the so-called Green Paper in which the Commission has summarised the status of the EU fisheries and also put themes and questions up for discussion. The themes and cases of this note address issues which feature prominently in the Green Paper: reduction of over-capacity by establishing rights-based management systems, increase of the responsibility of the industry through development of co-management arrangements, and reduction of the discard of fish.

The waters surrounding the Nordic countries are rich in fish resources. Up to this date fisheries has been among the most important productive sectors in the Nordic economies, and in the Faroe Islands and Greenland it is by far the most important sector. Management of marine fisheries has over time had various objectives in the Nordic countries, ranging from fiscal and social purposes to stock conservation and socio-economic wellbeing in recent years. There are strong similarities between the Nordic countries, but differences in ecosystem and the socio-cultural settings of the fisheries have lead to differentiated management systems anyhow.

Nordic experience in regard to fleet reduction by using rights-based management (RBM) systems shows:

- The introduction of RBM with transferability of rights has contributed to adjusting fleet capacity to the fish resources available for exploitation.

- With the reduction of the fleet capacity to match the TACs and fish quotas, the economic performance of the remaining active Nordic fishing vessels has improved significantly in all fleet segments - even though debts have increased as well. 
RBM has implications in other regards also, which could be addressed in the design of the systems:

- RBM systems can be designed to cater for social concerns in relation to small-scale fisheries and coastal communities through special coastal fisheries schemes or restrictions on allocation and transfer between regions and/or geographical areas.

- Another concern that has been addressed in the design of systems in some of the Nordic countries is the problem of increasing cost of investments for new fishers.

- Special quota funds for new fishers can lower the barrier to entrance created by the increasing cost of investments in the fishery. This is especially important for the livelihood of coastal communities.

The introduction of RBM systems is highly sensitive. In spite of the advantage in terms of economic efficiency etc., there is concern about the impacts on fishing communities and sector employment, but also about the principles applied for the allocation of fishing rights, and the distribution of the associated wealth. The Nordic experience is that the introduction of RBM should be adaptive and include an open discussion among all stakeholders about the features of the system in relation to policy objectives in fisheries and in society at large.

The Green Paper aims at creating industry responsibility for the CFP. Co-management or self-management are seen as tools for this. There are several Nordic examples of groups of fishers or broader groups of stakeholders taking responsibility for parts of the management of specific fisheries under co-management arrangements with consultative or advisory elements.

- The highest legitimacy of the regulations are found where the groups also have an advisory role, formal or informal, and their proposals and recommendations are included more or less directly into the management regulations.

Co-management arrangements bring out in the open potential conflicting interests which could be between fishers at local and national level and other groups seeking to get influence and a role in co-management ar- 
rangements (just as it is seen in the set-up of the RACs at the EU regional level). The cases illustrate that:

- High internal conflict levels in the co-management groups can sometimes reduce their capacity to influence decision-making, especially when the mandate for the group is unclear.

- With a clear mandate or room for manoeuvring, the cases show that stakeholder groups can take on responsibility and reach compromises, also when conflict levels are high.

- The potential for collective action and strong co-management engagement is even stronger within relative homogenous groups, like RBM groups with clearly delimited membership.

- Governmental agencies easily get directly involved in such conflicts, and the decision to lend authority to stakeholder groups, formally or informally, must be considered carefully.

Discard is waste of a precious resource, and prevents stocks from recovering in spite of low quotas. The fisheries systems in the Nordic countries apply a mix of effort and quota regulations as their main principles for regulating fisheries. The effort regulation in the Faroe Islands and the discard ban in the Faroe Islands, Iceland, and Norway seem to have had some success:

- Effort regulation, in combination with effective monitoring of fishing grounds, eliminates quota-related discard. Incentives to high fishing efficiency during the fishing days available may nevertheless lead to size-related discard, which still persists under effort regulation regimes without effective systems for monitoring, control and surveillance.

- Discard bans are combined with systems for control and enforcement and with legal mandates to intervene when the rules are violated.

- Discard bans are supported by technical measures regulating the use of gear, and also fishing period and place through closed areas.

- Tradition for co-management and general fisher influence means that the management of discard is considered reasonable and legitimate by the fishers, which also seems to influence the level of compliance.

- Discard bans are supported by incentives for the fishers to avoid discard. These incentives are economic benefits to the fishers for 
landing legal by-catch, even though most of the income is used for fisheries research, the opening up for flexibility in the quota allocation in order to adjust quota to catches, or the transferability of quotas, which means that fishers are allowed to buy quota after landing.

Further incentives for fishers to avoid discard are being discussed in Denmark. If the fishers through the use of electronic devises can document all catches and accept that they are all counted against the quota, then they have been offered the possibility of getting a share of what is set aside for discard in the TAC calculations. The acceptance of this new approach among fishers and in the political system is still to be seen.

There are lessons to be learned from the Nordic countries in the discussion of the revision of the Common Fisheries Policy. Various examples of solutions and models are seen, but a central lesson is that they have to be modified to suit the specific context. With this note we hope to be able to contribute to a widespread discussion of models and solutions, and also a discussion of how they can help solve the problems in the CFP as well as in management at local, national and regional level. 







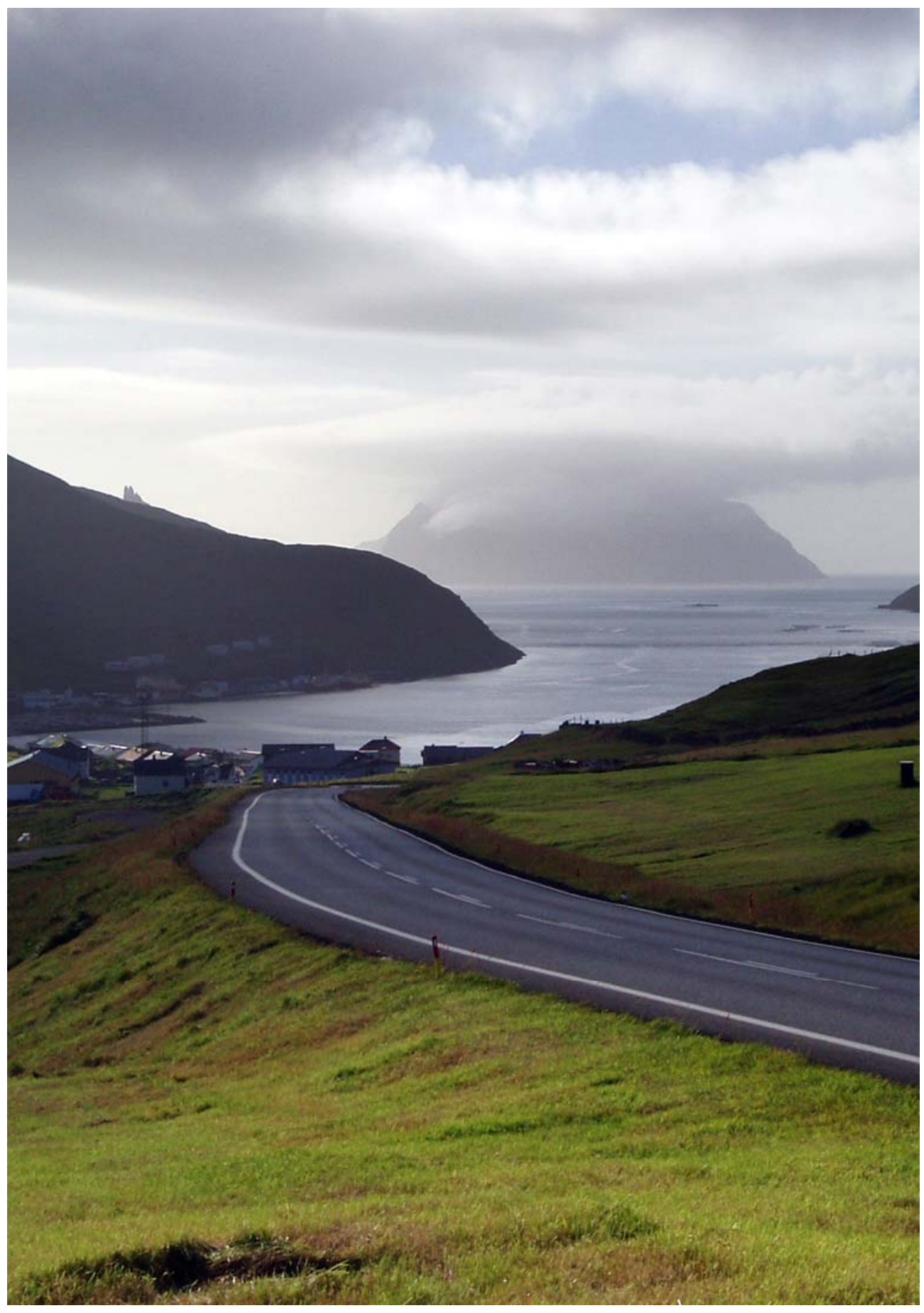




\section{Introduction}

The waters surrounding the Nordic countries are rich in fish resources. Throughout history, these resources have provided the livelihood of the many people settled along the long coastlines of the region. Up to this date fisheries has been among the most important productive sectors in the Nordic economies, and in the Faroe Islands and Greenland it is by far the most important sector. Key facts about the fisheries of the Nordic countries are shown in table 1 and on the map of the fishing territories in Figure 1.

Management of marine fisheries also has a very long tradition in the Nordic countries. In the course of time, the management systems applied have served various objectives, ranging from fiscal purposes (e.g. taxation of Danish and Swedish herring fisheries during the Middle Ages) over social purposes (e.g. zoning in the Norwegian cod fisheries in the Lofoten area, introduced in the 1890s to avoid gear conflicts) to stock conservation and socio-economic well-being in recent years.

Fisheries management beyond the $12 \mathrm{~nm}$ national zones was introduced unilaterally by Iceland in 1972 (50 nm) and 1975 (200 nm). After the establishment of the general $200 \mathrm{~nm}$ Exclusive Economic Zones in the North East Atlantic area in 1977, measures were immediately introduced in the Nordic fisheries to protect fish stocks from overexploitation. The ban on fishing for herring in the area marked the beginning. It was in the wake of this ban and the crisis in the Nordic pelagic fisheries that rights-based management schemes in the form of licenses and individual quotas were introduced in Norway and Iceland respectively during the 1970s. Since then the fisheries management systems applied in the Nordic countries have been under constant development to meet the dynamics of policy objectives related to resource protection and utilization, industry economic performance and social concerns. 


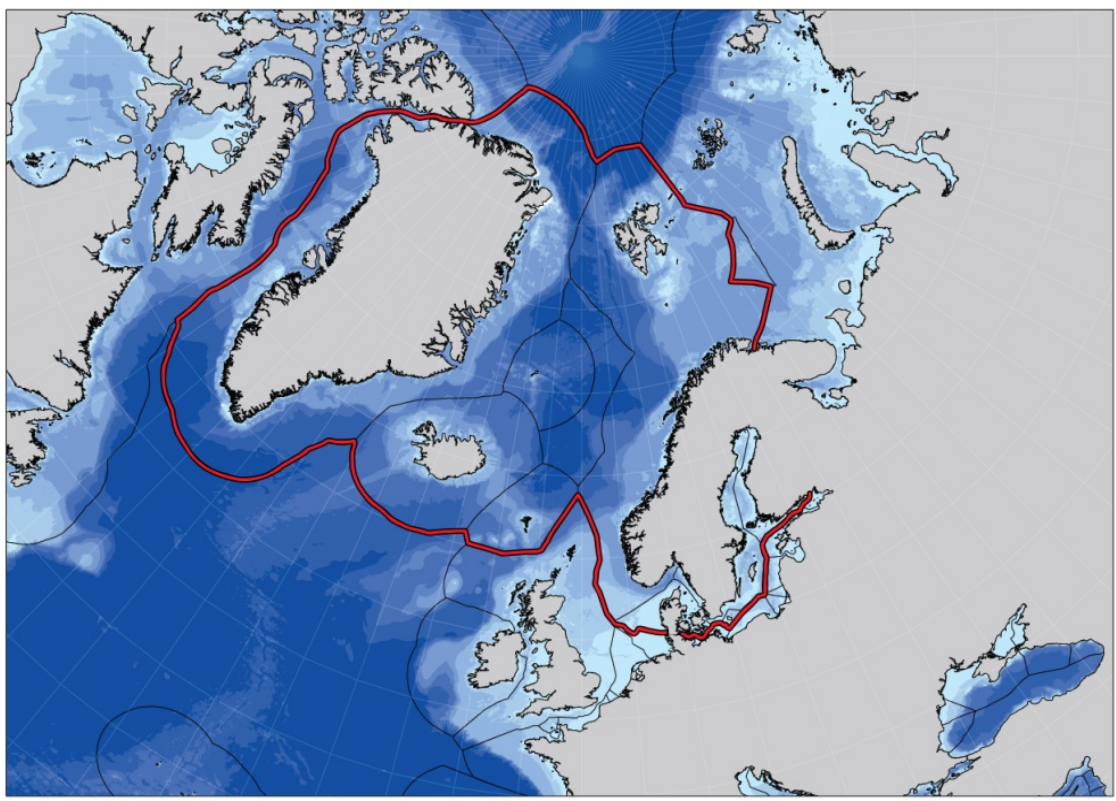

Figure 1: Nordic sea areas

Despite the differences in both the ecosystem and the socio-cultural setting of the fisheries, there are strong similarities between the Nordic countries and the EU countries as regards the sector policy priorities and the associated management problems. To some of these problems the Nordic countries have found solutions that may be of interest to the EU in the ongoing process of revising the CFP.

In this note, Nordic experience relevant to the reform of the CFP is described. The cases selected address issues which feature prominently in the CFP Green Paper. While there are important lessons to be learned from the Nordic fisheries, it is important to note that some models cannot easily be transported. A solution that works well in Iceland or Norway may require substantial modification in order to be useful in an EU context. Therefore, when evaluating the Nordic experience in relation to the CFP reform, the specific contexts must be kept in mind. Despite common socio-cultural roots and traditions in the Nordic countries, the social, economic, political and ecological circumstances, towards which the solutions to common problems in the fisheries have been developed, differ significantly from country to country. 
The issues addressed are firstly the overcapacity in the fishing fleets and the bad economic performance throughout the industry. The presentation of the Nordic experience focuses on the outcome and the process of changing fisheries management regimes towards rights-based management (RBM) systems - and systems with transferable rights in particular.

Table 1: The Nordic Fisheries in short terms

\begin{tabular}{|c|c|c|c|c|c|}
\hline & $\begin{array}{l}\text { Fishermen } \\
\text { (2008) } \\
\text { (Finland 2006) }\end{array}$ & $\begin{array}{l}\text { Value of landigs } \\
\text { by national } \\
\text { seafishers } 2008 \\
\text { (million } € \text {, total } \\
\text { and main spe- } \\
\text { cies) }\end{array}$ & $\begin{array}{l}\text { Fisheries share } \\
\text { of national GDP } \\
\text { (2008) } \\
\text { Agriculture, } \\
\text { hunting, forestry } \\
\text { and fisheries } \\
\text { share of GDP }\end{array}$ & $\begin{array}{l}\text { Value of } \\
\text { landings } \\
\text { per capita } \\
\text { (€/person) }\end{array}$ & $\begin{array}{l}\text { Fish and } \\
\text { seafood of } \\
\text { total export } \\
2008\end{array}$ \\
\hline Denmark & $\begin{array}{l}4,604, \text { of } \\
\text { which } 1,382 \\
\text { are vessel } \\
\text { owners }\end{array}$ & $\begin{array}{l}\text { Total: } 344.4 \\
\text { Cod: } 52.3 \\
\text { Herring: } 37.9 \\
\text { Mackerel: } 34.8\end{array}$ & 0,01 \% (2008) & 63 & $3 \%$ \\
\hline $\begin{array}{l}\text { Faroe } \\
\text { Islands }\end{array}$ & 1,837 & $\begin{array}{l}\text { Total: } 121.5 \\
\text { Saithe: } 34.9 \\
\text { Cod: } 32.0 \\
\text { Haddock: } 11.3\end{array}$ & $\begin{array}{l}16,2 \% \\
\text { (mainly fish) }\end{array}$ & 2511 & $82 \%$ \\
\hline Finland & $\begin{array}{l}\text { Sea: } 667 \text { full } \\
\text { time, } 1,412 \\
\text { part-time. } \\
\text { Inland: } 300 \\
\text { full time, } 350 \\
\text { part-time }\end{array}$ & $\begin{array}{l}\text { Total: } 23.1 \\
\text { Baltic herring: } \\
11.9 \\
\text { Sprat: } 3.0 \\
\text { European white } \\
\text { fish: } 2,6\end{array}$ & $\begin{array}{l}3,0 \% \\
\text { (forestry impor- } \\
\text { tant) }\end{array}$ & 4 & $<0,1 \%$ \\
\hline Greenland & No data & $\begin{array}{l}\text { Total: } 181,4 \\
\text { DW Prawn: } \\
125.3 \\
\text { Grl. Halibut: } \\
25.3 \\
\text { Cod: } 17.3\end{array}$ & No data & 3212 & $85 \%$ \\
\hline Iceland & No data & $\begin{array}{l}\text { Total: } 538.9 \\
\text { Cod: } 175.2 \\
\text { Haddock: } 82.2 \\
\text { Redfish: } 50.1\end{array}$ & $4,8 \%$ (2008) & 1719 & $32 \%$ \\
\hline Norway & $\begin{array}{l}10,307 \text { full } \\
\text { time, } 2,597 \\
\text { part-time }\end{array}$ & $\begin{array}{l}\text { Total: } 1,335.3 \\
\text { Cod: } 402.4 \\
\text { Herring: } 302.6 \\
\text { Mackerel: } 151.5\end{array}$ & 0,06 \% (2008) & 282 & $4 \%(2007)$ \\
\hline Sweden & $\begin{array}{l}1,807 \text { with } \\
\text { license as } \\
\text { commercial } \\
\text { fishers }\end{array}$ & $\begin{array}{l}\text { Total: } 95.3 \\
\text { Herring: } 23.7 \\
\text { Cod: } 18.2 \\
\text { Sprat: } 14.0\end{array}$ & $\begin{array}{l}1,2 \% \text { (agricul- } \\
\text { ture and for- } \\
\text { estry important) }\end{array}$ & 10 & $1 \%$ \\
\hline
\end{tabular}

Note: Calculations to $€$ as of 31/12-2008: DKK (Denmark and Faroe Islands) to Euro: 7.43 DKK to $1 €$; Iceland: 184 ISK to $1 €$, Norway: 8.5121 NOK to $1 €$; Sweden: 10.1659 SEK to $1 €$. 
The second issue relates to the legitimacy of fisheries management and fishers' compliance with rules and regulations. If these two things are not achieved the sector policy objectives cannot be met. The Nordic experience with fisheries co-management has shown ways forward in this critical area, even if many problems still remain.

The third issue addressed is the loss of fish resources because of discard at sea. In the Nordic countries ways and means have been found to overcome the problems involved, even in complex multi-species fisheries (mixed fisheries) that are also found in the EU fisheries. 


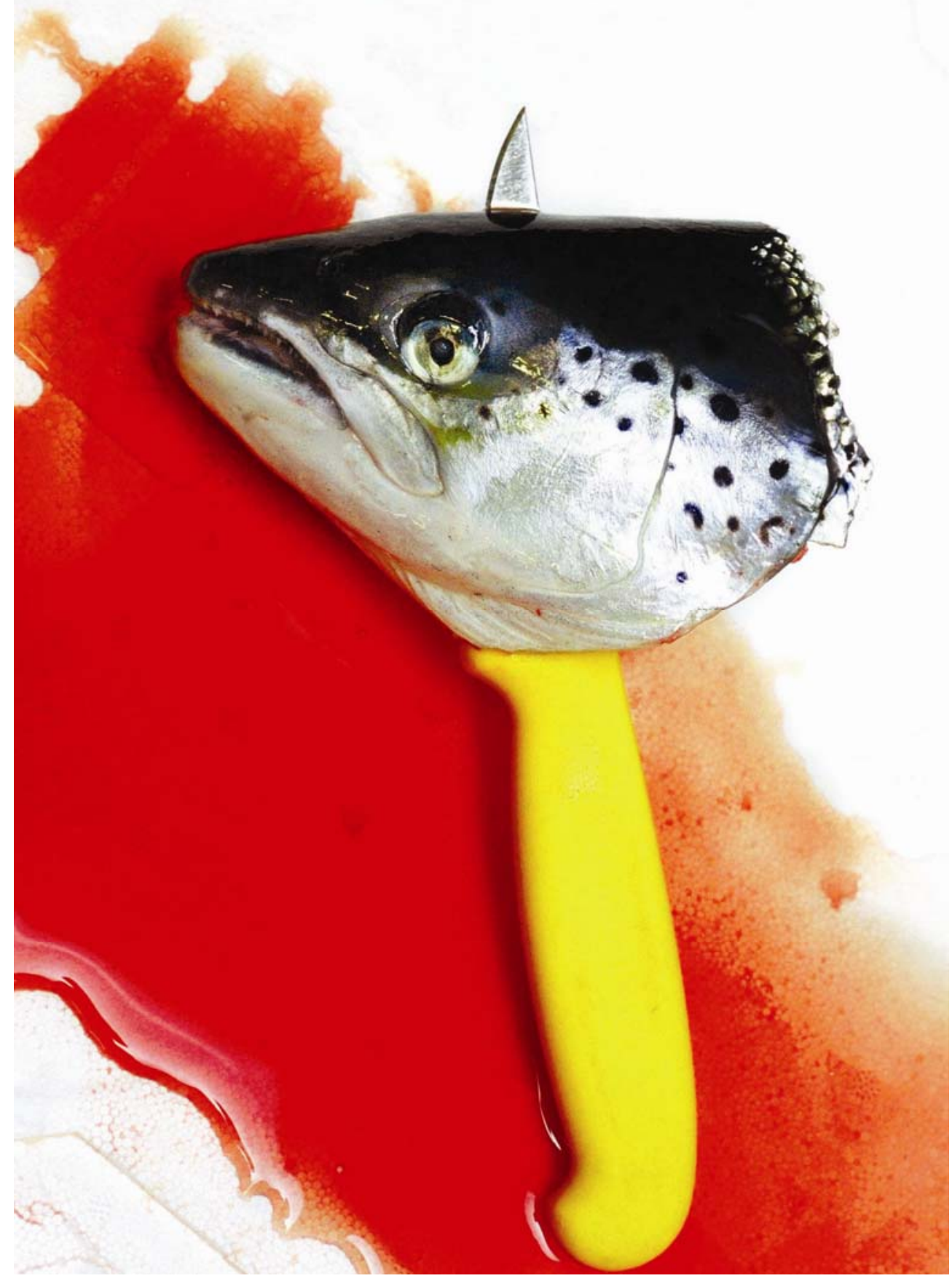




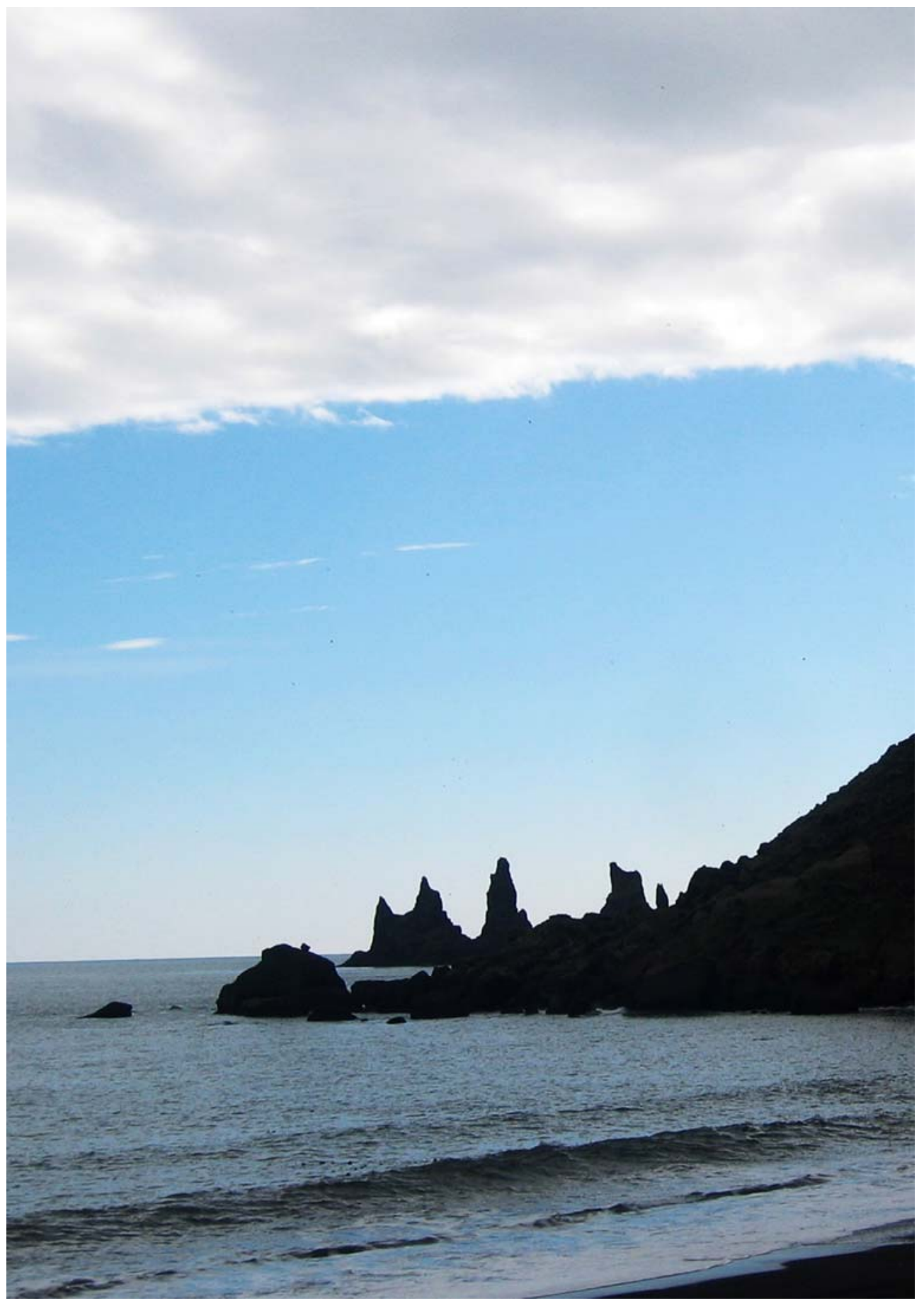




\section{Nordic experience of rights-based management}

Rights-based fisheries management, RBM, is based on legal fishing rights allocated to fishermen, fishing vessels, enterprises, cooperatives or fishing communities. Legal rights are rights that can be asserted against the state and third parties and enforced, as necessary, through the courts.

Under the heading of property rights different types of rights exist in the fisheries. These include use rights, access rights, harvest rights and ownership rights. All fisheries involve some rights. Access rights are very common and are restricted to an identifiable group of rights holders. Other rights in fisheries include the right to employ a certain type and quantity of gear, use certain types of fishing capital including boats, engines, fish finding equipment and other equipment, enter certain areas at certain times, extraction by species, time and quantity and so on. In fact for most commercial fisheries a bundle of rights must be acquired to harvest fish in a particular fishery. Thus, for instance, a fishing enterprise may be required to obtain a fishing licence, to use specified registered vessels, to obtain certain area-time fishing rights and several quantitative extraction rights (quotas) to a number of species.

OECD has developed a typology of the RBM systems applied in fisheries. This typology is shown in table 2. All the RBM systems listed are represented in the Nordic countries. 
Table 2: OECD typology of RBM systems

\begin{tabular}{|c|c|}
\hline RBM type & Key features \\
\hline Territorial Use Rights (TURFs) & $\begin{array}{l}\text { Allocation of a certain area of the ocean to a single user, usually } \\
\text { a group, who then undertakes fishing by allocating rights to } \\
\text { users within the group. }\end{array}$ \\
\hline $\begin{array}{l}\text { Community-based catch quotas } \\
\text { (CQ) }\end{array}$ & $\begin{array}{l}\text { Catch quotas are attributed to a 'fishing community' with deci- } \\
\text { sions on allocation of rights within the community taken on a } \\
\text { cooperative basis. }\end{array}$ \\
\hline Vessel Catch Limits (VC) & $\begin{array}{l}\text { Restrict the amount of catch that each vessel can land for a } \\
\text { given period of time (week, month, or year) or per trip. }\end{array}$ \\
\hline $\begin{array}{l}\text { Individual Non-Transferable } \\
\text { Quotas (IQ) }\end{array}$ & $\begin{array}{l}\text { Provide a right to catch a given quantity of fish from a particular } \\
\text { stock, or, more usually, a percentage of the Total Allowable } \\
\text { Catch (TAC). }\end{array}$ \\
\hline $\begin{array}{l}\text { Individual Transferable Quotas } \\
\text { (ITQ) }\end{array}$ & $\begin{array}{l}\text { Provide a right to catch a given quantity of fish from a particular } \\
\text { stock, or, more usually, a percentage of a TAC which is then } \\
\text { transferable (sale, leasing, loan). }\end{array}$ \\
\hline $\begin{array}{l}\text { Limited Non-Transferable } \\
\text { Licences (LL) }\end{array}$ & $\begin{array}{l}\text { These licences can be attached to a vessel, to the owner, or to } \\
\text { both and have to be limited in number and applied to a specific } \\
\text { stock or fishery to be considered as market-like. }\end{array}$ \\
\hline $\begin{array}{l}\text { Limited Transferable Licences } \\
(L T L)\end{array}$ & $\begin{array}{l}\text { By making limited licences transferable, fishers are provided } \\
\text { with an increased incentive to adjust capacity and effort over the } \\
\text { short to long term in response to natural and economic condi- } \\
\text { tions. }\end{array}$ \\
\hline $\begin{array}{l}\text { Individual Non-Transferable } \\
\text { Effort Quotas (IE) }\end{array}$ & $\begin{array}{l}\text { Rights are attached to the quantity of effort unit that a fisher can } \\
\text { employ for a given period of time. }\end{array}$ \\
\hline $\begin{array}{l}\text { Individual Transferable Effort } \\
\text { Quotas (ITE) }\end{array}$ & $\begin{array}{l}\text { Transferability makes short- and long-term adjustment easier } \\
\text { and allows for a better use of fishing capacities. }\end{array}$ \\
\hline
\end{tabular}

RBM, like legislation in general, is a tool to achieve society's social, economic, environmental and other objectives. The effectiveness and efficiency of a RBM approach to fisheries management should be judged on the extent to which these objectives are met, rather than on the extent to which certain notions of "quality", for example in terms of legal security and transferability, are fulfilled.

\subsection{The Green Paper on rights-based management}

The EU Green Paper Reform of the Common Fisheries Policy points to the fishing fleet overcapacity in the EU as the root cause of the overexploited fish resources and the weak economic performance of the European fishing industry. The problem of fleet overcapacity has remained for years despite various scrapping schemes and other structural measures. 
The Green Paper poses the question if transferable rights (individual or collective) could be used more to support capacity reduction for large-scale fleets and, if so, how could the transition be brought about. The paper also asks what safeguard clauses should be introduced.

\subsection{Rights-based management in the EU}

Rights-based management systems in place in EU coastal Member States cover a wide range of fleet and fishery types. All EU Member States have implemented some type of RBM, even though Slovenia is in the process of establishing a licensing regime. Limited licensing is a common means of restricting access to a fishery, and the majority of Member States use this either as a main, or supporting, means of managing one or more fisheries. In stocks managed by TAC, Member States have implemented a variety of individual quotas, individual transferable quotas and Vessel Catch Limit systems. In most cases, the extent of transferability officially enshrined in the system reflects national policy and concerns about the potential for rights to be captured by large and/or foreign interests. Quota-based systems are almost non-existent in the Mediterranean (bluefin tuna being the exception); there the management is mainly based on licensing and effort-based controls. Territorial use rights have been established across the EU, mainly for inshore and sedentary stocks. Effort-based systems are also used, predominantly in the Baltic States, or in support of quota systems in North Sea fisheries.

A recent (2009) EU Study has provided a comprehensive inventory of the RBM systems in force in the Member States. The study discusses the characteristics and qualities of the various RBM systems, including impacts related to fleet capacity and economy. It also provides examples of "good practices" in relation to critical issues, such as "new (young) entrants", "coastal (smallscale) fisheries', "discard and unwanted by-catch" etc. This illustrates that the use of rights-based management has implications in many other regards than fleet reduction and economic performance. 


\subsection{Rights-based management in the Nordic countries}

The EU study includes RBM systems and experience from the Nordic EU countries, Denmark, Finland and Sweden. However, various forms of RBM systems have for long been practiced in marine fisheries in e.g. the Faroe Islands, Iceland and Norway. Norway was the first country in the world to introduce trawler licenses, and Iceland was among the pioneering countries to introduce Individual Transferable Quotas (ITQ) and has more than 25 years of experience with this system for regulating fisheries output. The Faroe Islands have for more than 10 years practiced an Individual Transferable Effort (ITE) system that regulates input and allows for the transfer of fishing effort (days at sea) between vessels. The Nordic non-EU countries thus have a lot of experience in fisheries management of relevance to the ongoing debate on the reform of the CFP. This experience also includes the process of "management system change', a subject that was not dealt with in the EU study. Here important lessons relevant to the CFP debate have been learned by the Nordic countries.

The ITQ/VTQ systems adopted in Denmark and now covering almost the entire fisheries sector were presented and discussed in the EU study. However, additional experience relevant to the CFP debate has been gained over the last year.

The long established RBM systems in Sweden and Finland particularly apply to inland and inshore fisheries, and RBM was only very recently adopted in the Swedish marine fisheries. As this note focuses on the marine fisheries, the experience from these countries is not included. Interested readers are referred to the EU study.

\section{Iceland}

Prior to the introduction of the ITQ system in the late 1970s, Iceland practiced a wide range of fisheries management systems. These included access licenses, fishing effort restrictions, investment controls and vessel buy-back schemes, all of which were found not to be satisfactory. The first ITQ systems were introduced in the herring fisheries, following the establishment of the Icelandic EEZ. Since then, the system has been extended in several steps. In 1984, a limited form of ITQs was introduced in the demersal fisheries, which are by far Iceland's most important fisheries. In 1991, a uniform and 
fairly complete ITQ system was adopted in all Icelandic fisheries, applying to all vessels above a certain minimum size. In 2004, the system was expanded to cover all commercial fishing vessels. Currently, the system comprises 25 fish species and about 35 different fisheries.

\section{Norway}

In 1973, when a resource crisis hit the pelagic industry, a license scheme was introduced in order to limit the number and size of the pelagic purse seiners. At the same time license schemes were also implemented for saithe seiners and for shrimp trawlers. This means that when Norway got its 200 miles EEZ in 1977 most of the offshore fleet had been regulated in order to curb further expansion in numbers.

The next step in establishing RBM in Norwegian fisheries was a quasiIQ regime in the cod fisheries in 1990. Due to a crisis in the cod fisheries, the total quota had to be dramatically reduced, and open access had to be closed, dividing the coastal fishers in two groups: Group I, with guaranteed individual quotas granted according to vessel size and previous participation, and Group II, originally with maximum quotas within a limited group quota, resulting in an Olympic fishery. While the remedy originally was intended as a crisis measure, it soon turned out to be beneficial to the ones with guaranteed quotas. Hence, during the last ten years more and more fisheries have been closed according to the same principle: a participation right based on previous participation and a minimum catch in a qualifying period. As of 2009 most Norwegian fisheries of economic importance are closed, either by limiting access (Group I and II) or by specifying the removal right in terms of quotas. There are detailed allocation keys for all the major fish stocks, specifying group quotas for the different fleet groups. Details on the quota allocation process in Norway can be found in Chapter 2 on co-management experience.

\section{The Faroe Islands}

In the beginning of the 1990s the Faroe Islands experienced catches at a historically low level from the most important demersal fish stocks. This fostered a severe economic crisis in the fishing industry. As the regulation of the fishery was based on the use of technical regulations only (closed 
areas and mesh sizes), it was decided to introduce a more effective fisheries regulation.

An ITQ management system was introduced in 1994 for vessels of 20 GT and above whereas the smaller coastal fishing vessels would be fishing on a general annual quota. This system was met with much reluctance from both the fishing industry and a number of politicians and caused a substantial revision of the Commercial Fisheries Act. The reason for the reluctance is explained in paragraph 2.3.6 below.

The main elements of the RBM managements system applied in the Faroe Islands since 1997 are:

- A capacity policy which limits the size of the fishing fleet to the existing (1996) level.

- A grouping of the fishing fleet into vessel segments based on size and type.

- Allocation of individual and transferable rights to the industry by means of a dual license system comprising (i) catch permits which follow the individual vessels and outline the capacity for the vessel groups and (ii) fishing permits that are used for management of fishing patterns. The permits include the number of days at sea, which are used to regulate the catch of demersal species such as cod, haddock and saithe on the Faroe Plateau. A similar regulation is established for the Faroe Bank fishery. The regulation sets the number of days at sea that each individual vessel is allocated for a specified fishery. The number of days is regulated each year in a process including both scientific advice and advice from the industry.

- Technical regulations, including gear regulation and minimum size limits, and a system of closed areas regulating the admittance of the different vessel segments.

- By-catch quotas are used to regulate the fishery in the zone outside the Faroe Plateau.

\section{Denmark}

In 2003 ITQs were introduced in the Danish herring fishery on an experimental basis. The reason for the experiment was first and foremost the need for a modernization of the rather old Danish pelagic fishing fleet in 
order to meet the quality requirements of the fish processing industry. ITQs were allocated according to vessel track records for the previous 3 years. From 2007 the herring ITQ system was made permanent, and mackerel and industrial species, such as sandeel, sprat, blue whiting and horse mackerel, were put under ITQ management as well.

In 2007 a quasi-ITQ system (VTQ) was implemented in the Danish demersal fisheries for cod, saithe, plaice, haddock, hake, sole, turbot, monkfish, Norway lobster, and prawns. The major driving force behind this was the need to improve the economy of the demersal fishing fleet and reduce the pressure on demersal fish stocks (in particular from discard and high grading) through a substantial capacity reduction.

The main difference between the ITQ and VTQ systems is that in the former the quota can be transferred independently of the fishing vessels. In the latter the fish quotas (allocated on a 3-year historic record) and the vessels to which they are allocated are inseparable and only transferable together. However, a (new) vessel owner can transfer the quota utilisation to another fishing vessel in his possession, and if there is more than one (new) owner the quota utilisation can be split among them and transferred proportionately to other vessels in their possession. Fishers holding VTQs can form "quota pools" and through quota lease or swaps among pool members ensure efficient use of the pool's fleet capacity, and at the same time the discard related to individual quota limitations is reduced. Quota loans between fishing vessels outside quota pools are also permitted with some limitations.

Since 2009 the tying of the demersal fish quotas to vessels has been abolished, and the VTQ system has thus been turned into a proper ITQ system. In 2009 the Danish blue mussel fishery has also come under ITQ management, meaning that all Danish commercial marine fisheries are now managed through an ITQ system.

\subsubsection{RBM and fishing fleet capacity}

Economic theory suggests that with the application of transferable longterm use rights to fish resources the market forces will ensure that fishing fleet capacity (number and type of vessels and fishing technology applied) will be adapted to potential quota uptake through the process of maximizing profit/resource rent from the fishery. 
After the implementation of the IVQ system in Iceland in 1984, a reduction in the fishing fleet was expected. However, the fleet increased in both numbers and tonnage. This was especially the case with the tonnage of the trawling fleet and the number of open boats. With the adoption of a full-fledged ITQ system in 1991 the overall number of vessels has decreased dramatically. Most considerable are the $70 \%$ decrease in the number of open boats, and the 92\% decrease in the trawler fleet to 65 in 2006. However, the average size and power of the trawlers have increased.

The trends for trawlers and open boats respectively have different explanations. In the case of the trawlers larger vessels were brought into the fisheries, and quotas were moved from less efficient vessels to more efficient vessels within the same fishing company - a trend towards a fleet consisting of few larger trawlers.

The open boats were initially excluded from the IVQ system. This loophole resulted in an explosive growth in the number of small vessels. In 1991 the number peaked at 1,325 vessels with a share of more than $20 \%$ of the cod catches. The small vessels have since 1991 been incorporated in the ITQ system, and their decline in numbers has been ongoing ever since. In 2004 the number had been reduced by $40 \%$.

In Denmark the number of vessels holding ITQs has been substantially reduced since 2003 with the transfer of quotas. As an example 34 vessels took part in the North Sea herring fishery in 2008, compared to 84 in 2003. As intended, some of the Danish vessels holding ITQs are brand new and have replaced vessels that were more than 25 years old.

In the Danish demersal fleet holding VTQs, the number of active vessels (vessels with registered landings) was reduced by more than $30 \%$ over two years. This is primarily a result of the opportunity of pooling vessel quotas. In a recent assessment of the capacity of the Danish fishing fleet it has been found that there is a good fit between the overall capacity of the active fishing vessels and the fish quotas presently available for Denmark. However, some structural changes within and between the fleet segments would be required to make the fit optimal.

In Norway the licenses in the offshore fleet and the IVQ-system, with quotas attached, in the coastal fleet did not remove overcapacity. Additional measures were needed, starting with publicly funded scrapping schemes. In the offshore fleet the possibility of merging licenses was introduced already in the early 1980s. The same applied to participation rights 
in the coastal fleet, where guaranteed fishing rights with quotas attached were bought and sold. However, the transfer system was cumbersome, and the markets for rights were never officially recognized. When state subsidies in the fisheries were gradually phased out in the early 1990s, it was obvious that the fishers themselves had to take greater responsibility for capacity adjustments. The government therefore introduced a structure scheme, offering the offshore fleet the possibility of merging licenses and keeping the right in perpetuity. The same applied to the coastal fleet, which was divided into two groups: (i) vessels of 15-28 meters were allowed to merge up to 3 quota rights on one vessel, while for (ii) the smaller coastal vessels $(<15 \mathrm{~m})$ a scrapping scheme was introduced, paid $50 \%$ by the state and $50 \%$ by the fishers themselves. This arrangement was, however, lacking in terms of political legitimacy, and a new scheme was introduced in 2007. In this scheme merged rights in both fleets could be kept for 20(25) years, while re-structuring in the coastal fleet was allowed down to vessels of $11 \mathrm{~m}$, but with the limit of gathering quotas from two vessels only.

In the Faroe Islands the number of vessels subject to effort regulation decreased by 6\% from 1997 to 2003, but the total tonnage of the fishing vessels did not change during the period, except for the coastal fishing vessels below 15 GT. This shows that a moderate increase in the average vessel tonnage (7\%) has taken place, and a corresponding development is observed as regards engine power. Unfortunately, there is no information available on the technological development in the fleet. For the fishing fleet segments not subject to days-at-sea regulation there has been a significant (relative) increase, both in the number of vessels and in tonnage and engine power.

The Nordic experience with ITQ and ITE is very much in accordance with economic theory. The fleets managed through ITQs and VTQs have since the adoption of such systems largely been adapted to total quotas and modernized to ensure effectiveness and efficiency in the use of the invested capital. The modest capacity reduction in the Faroe Islands' fleet after the introduction of effort regulation reflects that the fish stock situation in Faroese waters has improved significantly after 1997, and the associated large number of days-at-sea allocated to the fleet has prevented a pressure for capacity reduction. This might, however, change due to a difficult situation for central stocks during the last year. 


\subsubsection{RBM and fishing fleet economy}

The theory on economic efficiency suggests that in a system with transferable long-term use rights the fishing fleet economy will improve for the vessels left in fleet. This would be due to adaptation of the fishing fleet capacity and its utilization, leading to reduction of costs of operation and maximization of revenues from fishing.

The economic viability of the Danish fishing fleet has improved significantly with the introduction of ITQs and VTQs. For the commercial fleet in total the profitability in 2007 was $20 \%$ (up from a 9\% average for the years 2004-2006). The increase was realized in spite of an overall $7 \%$ reduction in the Danish quotas for fish for human consumption from 2006 to 2007, and a 25\% reduction in the quotas for fish for fish meal and oil.

For all VTQ vessels the profitability has increased in 2007 when compared to the previous 3 years' average, and for some segments (e.g. demersal trawlers above $18 \mathrm{~m}$ ) the increase is more than $50 \%$. It should, however, be mentioned, that during the consolidation process the size of debts in the sector has increased considerably.

In Iceland the economic performance of the fishing fleet has improved significantly with the application of the full-fledged ITQ system. With annual net revenues in the demersal fleet (all segments) ranging from 13 to 19\% during the period 2001-2007, fisheries has shown to be among the most profitable economic sectors in Iceland.

The much improved economic performance of the Icelandic fishing fleet has paved the way for the introduction in 2004 of a "resource fee" payment (resource rent tax), which has been fully implemented in 2009 (9.5\%). The fee goes to the treasury with no strings attached.

The economic performance of the Norwegian fishing industry has improved with the implementation of the RBM system. Having acquired one or two extra quotas, many coastal vessels are now able to fish all the year round, with good salaries for their crew members. However, debts have also increased significantly in some fleet groups.

In the Faroe Islands there are no indications that the economic efficiency has increased with the introduction of effort regulation, including the possibility of transferring effort rights. For the large vessels subjected to effort regulation no significantly improved profitability has been seen, compared to vessels which are not subject to effort regulation. A major reason could be that both catch quantity and prices have been on their way 
up during the last decade, and therefore there has not been an external pressure for improving economic efficiency. This is also reflected in the relatively low number of effort transfers that has taken place.

The Nordic experience with the impact of RBM systems on fishing fleets' economic performance are that profitability has increased with the adoption of ITQ/VTQ systems, even if there have been reductions in the quotas, decreasing fish prices and increases in the costs of operations. However, the ITE system in the Faroe Islands does not seem to have impacted much on fleet economic performance.

\subsubsection{RBM and new entrants}

The capitalization of fishing rights that is associated with RBM systems will increase the entrance costs to the fisheries and thus make it more costly for young fishers to enter the industry. Therefore special provisions need to be made to facilitate the entrance of new fishers where this is a political priority.

The Danish ITQ/VTQ management system introduced in 2007 includes special provisions to accommodate new entrants below the age of 40. Each year a small percentage of the national quotas are set aside in a "Fish Fund" from which new entrants can obtain quota loans for a period of up to eight years. By August 2009, 20 fishers have taken such quota loans.

In Norway 30 new Group I guaranteed coastal quota rights have been allocated for free to young fishermen in 2009.

The Faroe Islands and Iceland have no special scheme for new entrants. Icelandic citizens have a general right to obtain a fishing license on demand, but newcomers have to either permanently buy or temporarily lease a quota to be able to fish. The "community quotas" introduced in Iceland in 2002 (see 2.3.5 below) may serve the purpose of facilitating new entrants.

\subsubsection{RBM and coastal (small-scale) fisheries}

Coastal small-scale fisheries are for various reasons often found less profitable than large-scale industrial fisheries. Therefore, fisheries management systems with long-term transferable use rights are often associated with quota concentration on larger vessels. To maintain small-scale coastal fish- 
eries special provisions would therefore often be required where this is a political priority.

In Iceland special conditions apply to vessels under 15 tonnes, which is now the legally defined limit for being a small vessel. This includes that quota can be transferred to the small vessels from vessels larger than 15 GRT, but not the other way round.

In Norway it has for long been a political priority to maintain the coastal fleet. This is reflected both in the way the RBM system was initially designed and also in the way it has developed with detailed allocation keys for the different fleet groups. Details on the quota allocation process in Norway can be found in Chapter 3 on co-management experience.

The Danish VTQ system includes a sub-programme aimed at maintaining small-scale coastal fisheries. The programme allows VTQ vessels up to a maximum length of 17 meters that meet some special criteria on their fishing activity to obtain additional annual rations of cod and sole that are set aside in the "fish fund". Out of 352 fishing vessels having joined the sub-programme in 2007, 340 were still included by April 2009. The share of (some) quotas belonging to vessels in the coastal programme has increased during this period, indicating that fishing rights have actually been traded into the coastal segment. To what extent this is sufficient to maintain all segments of the small-scale fisheries is still under discussion.

The Nordic experience is that it is possible to design a RBM system in such a way that it contributes to the maintenance of coastal small-scale fisheries. However, it should be observed that the overall development trend in the fishing industry is towards vessels that are comfortable, safe and efficient in fishing operation and catch handling, weather independent etc., and thus often bigger in size. This also applies to the coastal vessels, with a reduction in numbers as the logical outcome. Design of RBM systems would have to take this trend into consideration.

\subsubsection{RBM and fishing communities}

The concentration of transferable rights on larger vessels in order to realize "economies of scale" involves the risk that local fishing communities may lose critical mass with severe impacts on the supply of local services etc. to the fishing industry and on local employment as a consequence. 
In Norway the maintenance of the dispersed coastal settlement structure has for long been a political priority. Despite the mitigating measures, such as restrictions on quota transfer between counties, that are taken when designing and developing the Norwegian RBM system, the trend is concentration. This leaves many coastal villages, particularly in the northern part of the country, with fewer boats, less employment, and over time a reduced population. However, as in Iceland and elsewhere this development also depends on other important factors in the labour market.

The Danish experience from introducing ITQ/VTQ shows no signs of development of a particular pattern in terms of geographical concentration of quotas. Esbjerg, once one of the biggest fishing communities in Denmark, has lost a significant amount of quota shares and vessels, while Thorupstrand, where they fish from the beach, is one of the fishing communities being most successful in acquiring quota shares.

Neither is there any evidence of geographical concentration within regions in Denmark. The 352 vessels that joined the Danish VTQ coastal subprogramme in 2007 represented close to 100 fishing communities. Until May 2009 there have been no signs of geographical concentration in this segment.

Community quotas were introduced in Iceland in 2002 to address some of the criticism of the ITQ system, specifically the effect of quota consolidation in larger communities resulting in migration of people away from smaller communities. The term "community quotas" refers to a small part of the TAC (currently around 4,000 tonnes of cod equivalent) that is given to about 20 small fishing communities on an annual basis. The introduction of community quotas was highly controversial and has caused legal problems as the allocation is based on a formula of employment, fisheries dependency and whether quotas have initially been transferred from the area. There is no legal provision for community quotas. It is the Minister who decides if the allocation will be made and how.

The regulation on community quotas was reviewed before the fishing year 2007/08. Until then the small villages had decided for themselves who in the community should get the quota. This caused some problems because they all knew each other, and everybody wanted the quotas. The changes were made to ensure that the allocation process is running smoother, and that communities, and not vessel owners, are supported.

Another measure adopted to support local fishing communities is that the quotas for the longliners having their lines prepared on shore are set 16 
per cent higher than for those who do not. This measure both enhances the longline fishery, which is considered sustainable in biological terms, and preserves onshore jobs in local communities.

In Iceland it is still highly contentious what the effect is of quota trading per se on the development of fishing communities. The most recently published study on the issue does not find any particular patterns or trends.

Consequently the Nordic experience does not support the assumption that RBM systems, with transferability of fish quotas or fishing effort, necessarily imply geographical concentration of fishing vessels and associated services. However, the risk is high that RBM systems in fisheries may reinforce already ongoing processes to that effect. Therefore, if maintaining coastal settlements is a political priority associated with RBM, then special provisions (e.g. on the transferability of rights) should be made to safeguard that critical mass will continue to exist in the fishing communities.

\subsubsection{The process of adopting $R B M$}

Moves towards fisheries management systems that increase exclusivity and concentration of rights are always associated with substantial dissatisfaction not only among those likely to be excluded or otherwise left behind, but also among the (potential) beneficiaries, who are often strong supporters of the principles of "open access" and "equal rights for all” that was the marine fisheries "ideology" for generations.

Why was a full-fledged ITQ system not introduced in Norway right away? The answer is that Norwegian fisheries policy is cast in a totally different setting than in e.g. Denmark and Iceland. The idea of public ownership to the marine resources, and a political commitment relating to employment and a dispersed settlement pattern, have always been strong factors in Norway. Hence, a proposal of introducing an ITQ scheme in 1991 was quashed after a short political battle.

The Norwegian system of RBM is thus a jigsaw puzzle, worked out at different times and for different political purposes. While both the offshore and coastal fleets are moving closer to a classical ITQ-system with transferable licenses/participation rights and quotas attached, the Norwegian system still includes a set of peculiarities: First of all, the right to own a fishing vessel is still protected by law. You have to be an active fisher in order to be a majority owner of any vessel. Second, the participation right, 
which can now be bought and sold openly within Group I coastal vessels, is technically granted for one year at a time only, thus securing a strong sense of state ownership. (Norway does not allow the plain buying and selling of quotas as such, while temporary transfers have been allowed up to this year). Third, in the important cod, saithe and haddock fisheries mergers and sales of vessels with participation rights can only be done within the same county and within the same size group.

In Denmark during the last decade resistance against ITQ systems was fierce, especially among demersal fishermen: This resistance fostered a lengthy debate, particularly within the fishing industry, on the design of the much needed "New Regulation" of the Danish fisheries. Based on the positive experience, in terms of improved economic performance and fleet structural adjustments, from the testing of the ITQ system in the herring fishery from 2003, the resistance softened. The proposal of a VTQ system was reluctantly endorsed by the Danish Fishermen's Association and adopted by the Danish Parliament in 2006. From January 2009 the tying of quota shares to the vessels to which they were initially allocated was abolished, establishing a de facto ITQ system comprising 99\% of Danish fisheries. Now most Danish fishermen are in full support of the RBM system. "Why wasn't this introduced much earlier?” is a frequently heard comment.

In the Faroe Islands, the fishing industry has in general accepted the management system regulating effort, and the Committee on Fishing Days, composed of representatives from the fishing industry, has suggested that all fisheries in the Faroe Islands should be regulated through days-at-sea allocations. This acceptance is in contrast to the reaction to the regulation with ITQs during the period 1994-96 that met strong resistance from the industry. The ITQ system was introduced through a "top-down approach" when the stock situation was critical and quotas for allocation were historically low. In the following period, where the effort regulation was introduced, the stock development has been extremely positive, concurrently with almost a doubling of the prices on cod and haddock. The acceptance of the regulation system may thus be influenced by the fact that both fish quotas and prices have developed positively, and that it has not been necessary to introduce significant restrictions on the fishery. The "bottom-up approach" taken this time, involving the industry and other local stakeholders in the design, has also provided legitimacy of the system among fishermen and a high level of compliance with the effort regulations. Pub- 
lic discussions regarding the system have, however, increased during the last year, which has been a period of problems in central stocks, such as cod and haddock, and decreasing cod prices.

Before 1991, the ITQ systems in place in Iceland were limited, in terms of fisheries and fleet coverage as well as in the quality of the property rights they defined. Several fisheries and fishing fleet segments were not included, and the continuation of the system was uncertain. Also transfers of quota rights were long-term affairs. As one result, quota holdings were generally not accepted as collateral by financial institutions. This changed in 1991 when ITQ was formally established as the permanent cornerstone of Icelandic fisheries management. Its coverage was greatly increased, and its legal and property rights attributes were clarified and strengthened.

\subsubsection{The ongoing debate on RBM}

In Iceland the ITQ system has been welcomed by the fishing industry, and the large-scale operators in particular, but discussions have continued regarding the impacts of the system on fishing communities, and the principles behind the allocation of fishing rights and the distribution of the associated wealth. Opposition against the system has increased in recent years, and one major concern has been that it may be very difficult to reverse the system. Many citizens feel that they have lost definitively what used to belong to them. To compensate society, the concept of "resource rent" has become increasingly central in the ITQ debate in Iceland. While the public largely supports the idea of a rent fee, in the light of the valuable large resources that have been handed over to the initial quota owners for free, the industry sees a resource rent fee as yet another tax that would decrease industry competitiveness. The outcome of the debate so far is the resource rent tax on quota holders that was introduced in 2004. An alternative, which is favoured by the present Government in Iceland, is that a percentage of the quotas should be returned annually to the State which would then in turn allocate it through an open auction.

In Norway there has also been a lack of legitimacy of the new RBM system, both inside and outside the industry. Whereas most people understand the logic of closing access, and thus giving stronger rights to certain fishers to achieve technical improvement, stable TACs and a salary level on par with the rest of the Norwegian labour force, the problem of windfall 
profits remain. This is the profit obtained by the few, through rights originally acquired for free and with no compensation paid to crew members or to the municipalities that have to shoulder the associated negative social consequences. The capitalized resource rent may be substantial, running up to 30 million USD in the purse seine fleet, while participation rights in the coastal fleet are traded in the range of USD 100,000 to 1 million. It should also be mentioned that not all people in Norway accept the state as the owner of the resources, not even as the sole distributor of access rights. The aboriginal people of the North, the Saami, have long claimed local rights and ownership, thus challenging the right of the state to manage all marine resources as national resources.

In Denmark there has so far been no public debate about the RBM system introduced, including the criteria for quota allocation and the distribution of the wealth obtained from the capitalization of the transferable fishing rights. The resource rent in Danish fisheries, which in 2007 was in the range of $9 \%$, has until now been left with the quota holders.

In the Faroe Islands the public debate about the RBM system has been limited until recently, whereas it has been discussed among economist and biologists (arguing for ITQ for economic reasons and for further effort reduction for ecological reasons respectively). During the last year the system has, however, been on the political agenda as an issue of allocation of national resources.

\subsection{Lessons learned from the Nordic countries}

The EU Green Paper, Reform of the Common Fisheries Policy, points to the overcapacity in the EU fishing fleet as the root cause of the overexploited fish resources and the weak economic performance of the European fishing industry. The paper poses the question if transferable rights (individual or collective) could be used to support capacity reduction in largescale fleets and, if so, how the transition could be brought about. The paper also asks what safeguard clauses should be introduced.

From the above short presentation of the RBM systems implemented in the Nordic countries over the last three decades it is clearly demonstrated that: 
- RBM systems with transferability of rights, and particularly ITQ/VTQ systems applying output control, have contributed to adjusting the fleet capacity to the fish resources available for exploitation (TACs). This is the common experience from Iceland, Norway and Denmark, despite the differences in sector structure and resource base. The effect on fleet overcapacity of RBM systems applying input control (ITE) has not been demonstrated because the fisheries situation in the Faroe Islands has not called for an overall capacity reduction, but only for a structural adaptation of the fleet.

- With the reduction of the fleet capacity to match the TACs and fish quotas, the economic performance of the remaining active Nordic fishing vessels has improved significantly in all fleet segments. However, the debts in the sector have also increased. With the adoption of RBM systems, the fishing industry in the Nordic countries has turned into a profitable economic sector, generating a sizeable resource rent.

- The experience from the Nordic countries as regards the adoption and implementation of RBM systems in the fisheries sector clearly demonstrates that such policy decisions are very sensitive to legitimacy among fishers and other stakeholders. Adaptive bottom-up approaches involving the stakeholders in the system design have shown to generate lasting solutions, whereas inflexible top-down approaches have largely failed. This experience applies to all the Nordic countries.

- The Green Paper raises the question if the CFP should adopt a "two tier" management regime: one for the large-scale fleets where capacity adjustment and economic efficiency is at the core, and another for the smallscale fleets in coastal communities with a focus on social objectives. The policy context for fisheries management in all the Nordic countries has for long been taking this dichotomy into consideration, and the RBM systems adopted have been designed accordingly. The experience in the Nordic countries shows that, even if ITQ/VTQ systems are particularly suited to cater for capacity adaptation and economic efficiency, they can be designed to cater for social concerns related to small-scale fisheries and coastal communities. This can either be through a special "coastal fisheries" scheme involving special rights (and obligations) as implemented in Denmark, or through restrictions on the quota allocation and transfer of quotas between vessel segments and/or geographical areas as practiced in Norway and Iceland. 
- Closely associated with the concern for the livelihood of coastal communities is the concern for new (particularly young) entrants to the fishery. This problem is in particular about meeting the increasing costs of investments, associated with most RBM systems, in both material assets (vessel and fishing gear) and immaterial assets, such as fish quotas, and it has been addressed in the design of the systems adopted in the Nordic countries. In Denmark the solution involves a "quota fund" from which young entrants can obtain quota loans for a period of time. In Norway there are special quota allocations available to new entrants, whereas Iceland addresses the concern for new entrants via the community quotas.

- The Nordic experience shows that the introduction of RBM systems is highly sensitive, despite "obvious advantages" in terms of economic efficiency etc. This relates not only to the perception of the impacts of such management systems on fishing communities and sector employment, but also to the principles applied for the allocation of fishing rights and the distribution of the associated wealth. The lesson learned from the Nordic experience is that the introduction of RBM should be adaptive and with an open discussion among all the stakeholders about the features of the system in relation to policy objectives in fisheries and in society at large. 


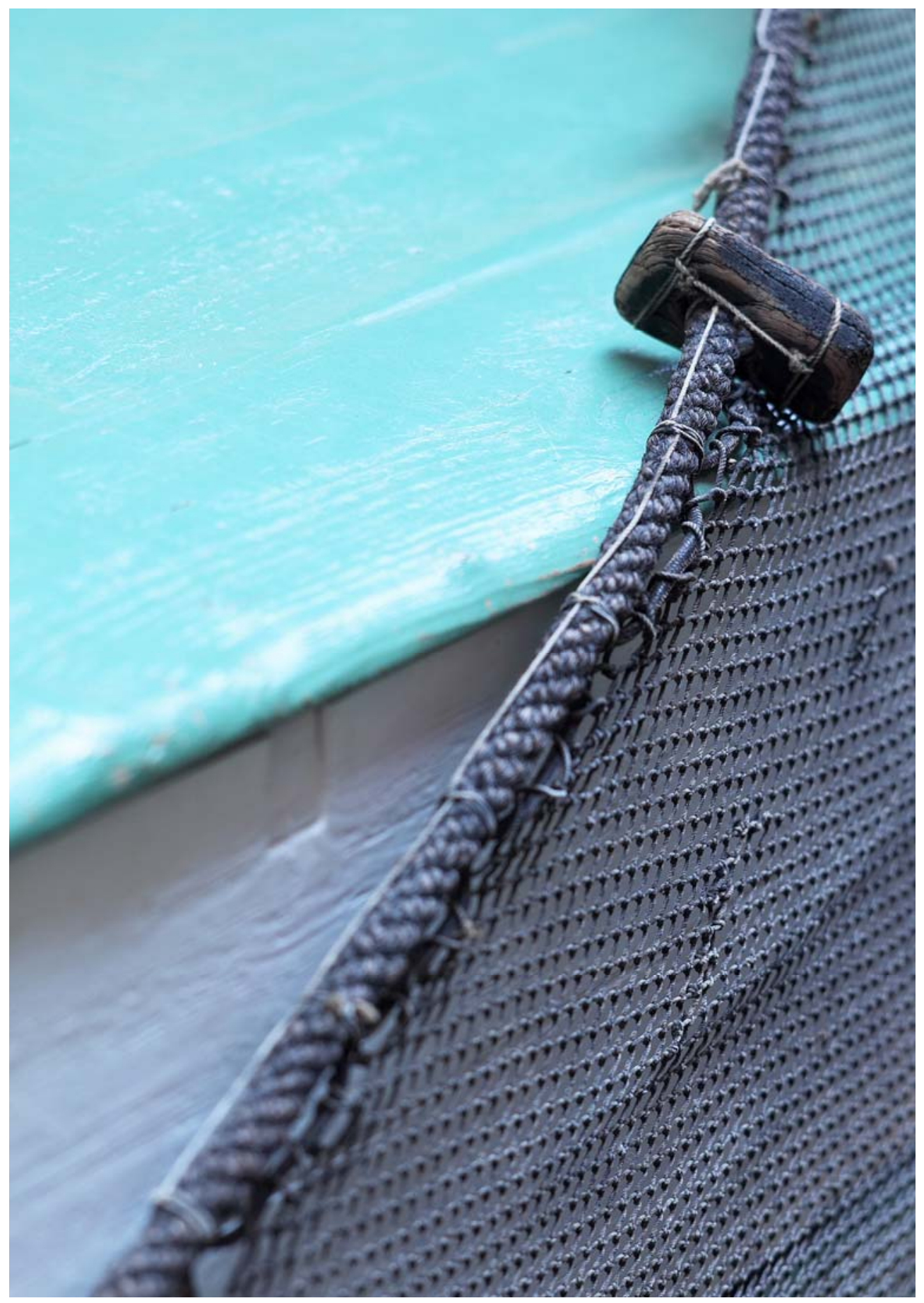




\section{Nordic experience of co-management}

Co-management is about involvement of the users of management, in this case mostly the fishers' involvement in the management of fisheries. It can be seen as a more democratic way to manage. But the managerial intentions are often to get more trustworthy data on catches and fishing practices so that better decisions about regulations can be made, regulations can be better implemented and a high level of compliance can be achieved.

Co-management covers systems with varying degrees of user involvement in the management.

With increasing fisher involvement, the co-management arrangements can be labelled as:

- Instructive management, where decisions are made in the government system, and fishers are instructed in decisions. This is not a co-management arrangement.

- Consultative co-management, where fishers are consulted on proposals before decisions.

- Cooperative co-management, between fishers and authorities as equal partners in developing proposals for management decisions.

- Advisory co-management, where fishers advise governments of decisions to be made, and the government endorses these decisions.

- Informative co-management, where governments have delegated the authority to make decisions to user groups, which are responsible for informing government about the decisions made. 


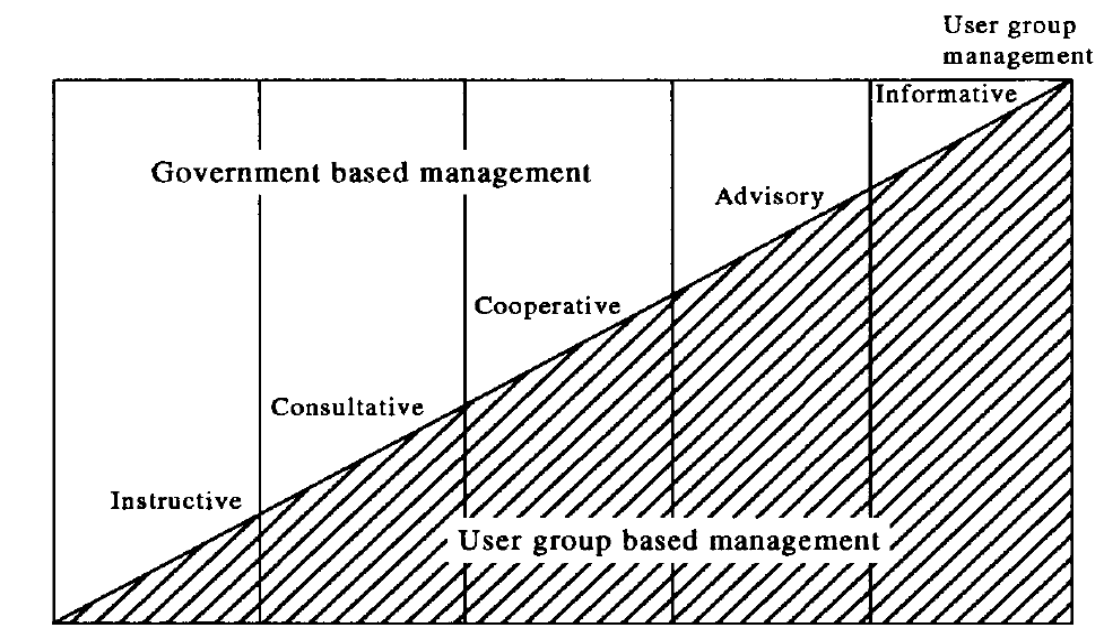

Government

management

Figure 2: Types of co-management

Self-management in a clear-cut version is hard to imagine in the modern society fisheries. There has to be some governmental involvement to regulate access to the fish resources and to secure sustainable resource use, but self-management within a general policy framework is possible. As an example TACs are set at EU level. Member States allocate the quota among user groups and leave it to the groups to self-manage the further allocation of the quota internally. This is seen in the POs in the United Kingdom and the quota pools in Denmark (see chapter 4). In these cases the fishers practice self-management within a framework set by a higher level of authority and under the condition that they report and document the quota uptake to the higher level. The delegation can be withdrawn if the self-management is not working as intended within the politically accepted framework.

\subsection{The Green Paper on co-management}

The Green Paper proposes to distinguish between deciding on the principles for the CFP and implementing the CFP. Principles and standards, such as fishing within MSY, adjusting fleet capacity to resources and abolishing 
discards, should still be decided at the EU level (Council of Ministers, EU Commission). Implementation of decisions could be delegated to the Member States for possible self-management by the industry. In that way there would be a higher flexibility locally and regionally, and micromanagement from Brussels could be avoided. The specific implementation should be in accordance with Community standards and under EU control.

Therefore the discussion of co-management and self-management in the CFP context is under the condition that the overall standards and principles for fisheries management are set at the EU level, and that implementation is subject to Community control. This can be Community initiated control or control of documentation received from the Member States or the industry.

Co-management and self-management is seen by the Commission as a tool for encouraging the industry to take on more responsibility in implementing the CFP. It is seen as "critical to the success of reform that industry should understand the need for it, support it and have a genuine stake in its successful outcome” (Green Paper, p. 10).

Co-management is seen as an alternative to the top-down approach taken until now in implementing the CFP. To involve the fishers in the management of Community fisheries through co-management or self-management arrangements will create incentives to act responsibly in regard to sustainable use of the fish resources as well as other principles in the CFP.

But how could this be done in practice:

- How can more responsibility be given to the fishing industry?

- How is industry best structured to take on more responsibility?

- Which mechanisms can supervise the self-management and ensure that the industry actually takes on the responsibility and acts in a responsible way?

\subsection{Co-management in the EU}

In the present CFP management system, the overall policies and principles of the fisheries policy are decided upon/revised every ten years by the Council of Ministers based on input from the EU Commission. The details in the implementation of the CFP are decided at the same level. In this top- 
down approach the stakeholders are involved in the decision-making in two consultative co-management arrangements.

The Advisory Committee on Fisheries and Aquaculture (ACFA), which is composed of interest groups representing the fishing industry, the processing sector, traders and employees within fisheries, as well as consumers and environment, was established in 1971 for the purpose of establishing a close dialogue with the fisheries sector and other groups affected by the CFP. The ACFA comments on proposals from the EU Commission before decisions are made, and ACFA has the possibility of raising questions on almost all other issues. In that way the ACFA can be seen as an institution for consultative co-management. It is consultations at a very high level and within a nested system, which tends to establish a long distance between the consultative arrangement and the practical fisher. This reduces the legitimacy effect of the process of being consulted.

The Regional Advisory Councils (RACs) were introduced with the reform of the CFP in 2002. The intention is to establish a higher involvement of the stakeholders at an early stage in the decision-making process. It was initially considered to delegate some decision competence to the RACs, but so far their role is only advisory. The RACs comment on proposals formulated by the Commission, but during their first years of existence the RACs have also taken own initiatives in formulating proposals. Such proposals from the RACs can be taken into consideration, but the Commission and the Council of Ministers are not formally obliged to take the proposals into consideration. Formally the function of the RACs should be labelled a consultative co-management arrangement, but depending on the political will the RACs could function as advisory co-management partners as well.

In the Member States different types of co-management arrangements exist for the country specific implementation of the Common Fisheries Policy.

\subsection{Co-management in the Nordic countries}

In the Green Paper the producer organisations (POs), which are central bodies in the CFP market policy, are mentioned as the type of institution that could be turned into bodies through which the industry could take on management responsibilities. In contrast to many EU countries the preva- 
lence and role of POs is limited in the Nordic countries, but the Nordic experience presented below show that other industry organisations at national and local level can take on the role of co-management partners or even self-managers.

The Nordic co-management experience includes the issue of ensuring stakeholder representation: Who is represented by the organisation? Is the internal authority of the organisation strong enough to bear the responsibility of the self-management or co-management?

The first case of co-management to be presented below is a formal consultative co-management arrangement in Norway. In this arrangement an informal advisory role is given to the Norwegian Fishermen's Association in the decision-making on principles for distributing shares of the TACs to different fleet categories. The formal consultative arrangement and the informal advisory arrangement co-exist with severe consequences for the many groups of stakeholders involved - and for the legitimacy of the decisions on quota allocations made.

In the second case focus is on co-management at the local level. In Sweden a Government led co-management initiative supported six local fisheries management groups. The groups should identify local problems and eventually draft and implement local management plans. The local groups consisted of fishers or a broader range of stakeholders and were formed with a high level of enthusiasm and energy. Having identified the management needs the groups began developing the local management plans. During this process it became clear that the mandate of the groups was not clear. The groups had no formal power to implement the plans, and no procedures were in place to take the plans to higher management levels for decision-making or even consideration. Some of the plans were simply overruled by other interests at national or EU level.

The third case focuses on the local self-established fisher groups in the mussel fishery in the Limfjord in Denmark. These groups have managed to get a strong, yet informal, advisory role in the local management by collectively developing fishing plans and other self-management initiatives within the framework of the formal regulations. A conflict between the fishers regarding the enforcement of internal agreements illustrates how public power over enforcement can be "borrowed" by the groups to achieve compliance and curb possible free-riding. 


\subsubsection{Formal and informal co-management in Norway}

Norwegian fisheries management has a strong tradition of user-group involvement. This tradition stretches more than 100 years back to the time when the fishermen became directly involved in the management of the famous Lofoten cod fishery. Since then, several important co-management arenas have been introduced in the Norwegian fisheries, both in the organization of the firsthand fish markets and in the bargaining about, for instance, state subsidies. Today, the most important area for user-group participation in fisheries management is quota management.

Most of the commercially important Norwegian fish resources are shared with other countries. Therefore, the TACs are negotiated and decided upon in various international fora. Representatives from the sector, most notably the Norwegian Fishermen's Association, form part of the Norwegian delegation in these negotiations. This allows the fishermen to be close to and have a say in the perhaps most critical management decisions.

The two most important arenas for user-group influence are within the national management of the TACs after they have been decided upon.

Firstly, there is a formal system of consultation, the Management Meeting (Reguleringsmøtet) which is held every year in October or November. Here, stakeholder groups are invited to present their viewpoints on the Government's management plans for the different fisheries for the coming year. The invitation is open and participation is granted to any group or individual who wants to participate. The meeting is hosted by the Directorate of Fisheries, which is also drafting the management plans. The Management Meeting has a consultative function, but the Minister of Fisheries and the Government make the final management decisions. However, firm advice from the core stakeholder groups is most often observed.

Secondly, there is an informal practice by which one of the stakeholder groups, the Norwegian Fishermen's Association (NFA), is granted a privileged role in connection with the formulation of the principles by which the Norwegian national quotas are distributed to fleet categories (segments). This practise developed from a hard-won compromise that was reached in 1989 and often is referred to as the "Trawler Ladder'. The compromise, which was accepted by the authorities as the basis for quota allocation in the 1990-94 period, divided the Norwegian cod quota between the coastal fleet and the trawler fleet in a variable proportion dependent on the size of the TAC/quota. The allocation key gave the coastal fleet a larger 
share of the catch when the TAC was low and the trawler fleet a larger share when the TAC was high. The Trawler Ladder is still in operation, although in a slightly modified form. Since 1994, the allocation system has been further developed and now includes all the commercially important Norwegian fisheries. The system has been extended with mechanisms for quota allocation among vessels within the main segments of the coastal fleet and the trawler fleet. The allocation keys, which are re-negotiated every 5 years, use a combination of vessel size and historical catch records.

In the co-management context the Norwegian government has left an important aspect of the fisheries policy, the annual quota allocation, to be decided in an internal process within the Norwegian Fishermen's Association. This is an informal and conditional arrangement; the Government remains in charge and is not formally obliged to follow the allocation principles established by the NFA. There has so far been a strong political commitment to this arrangement, a major reason for this being the Government's concern for the legitimacy of the quota regime. Through their representatives in the NFA, the fishermen are involved in the decisionmaking on an issue that directly affects their employment and income. While they surely may often want a different result for themselves, they do at least get an insight into the problems involved in working out a system for sharing a limited resource in a way that is acceptable to all parties. For the NFA, the task of reaching compromises on the quota allocation principles has been an extremely difficult, conflict-generating and timeconsuming task. At times, the strain on the association has been severe, involving the risk of breakdown. Until now, this has not happened, and the NFA has been rather successful in working out compromises. For the association, this has been very important as it demonstrates its willingness and capability to take on management responsibility in an extremely difficult and contentious area.

The system of user-group participation in Norwegian quota management has strengths as well as weaknesses. It is an obvious strength that the difficult task of quota distribution can be left to the industry itself. This not only relieves the government of a difficult and time-consuming task, but also lends legitimacy to the whole management system. It is, on the other hand, a weakness to delegate decision-making on a key issue to one stakeholder group only. This represents a legitimacy problem, since it means that other stakeholder groups are not given similar influence. So far, this 
reality has not caused major problems in Norway, partly because the fishermen are regarded as the dominant stakeholder group in this matter. This may change, both because of the decreasing size of the fisheries sector and because of the move of fisheries management towards rights-based management. As the fisheries are transforming from an "open access" sector with a broad support basis in the coastal communities into a more "privatized" sector, the delegation of important decision-making to the NFA may become problematic.

There is increasing criticism of the present allocation system for not taking the interests of the most fisheries-dependent communities into account. In particular, there is a criticism from the northern part of Norway, pointing to the trend that the coastal fisheries in the North are losing quota shares to the more industrial fisheries on the south-western coast. Despite heavy mobilization from members in the North, the NFA quota allocation system has not been able to prevent this. A major reason for this is the power balance within the association, where the North Norwegian representatives are not in a majority position. There are regional checks on quota transfers, but this has not been sufficient to keep up the North Norwegian quota share. Since a major societal and political goal attributed to the fisheries is to safeguard employment and economy in the peripheral regions of Norway, this has from North Norwegian side been emphasized as a serious problem with the present allocation system.

\subsubsection{Local co-management with unclear delegation of mandate}

In 2004 the Swedish government launched a co-management project (Samförvaltnings-initiativet) with the intention of gaining experience with different co-management forms and decision-making processes in local fisheries. The initiative was based on the hypothesis that "common resources are best managed in cooperation'. Within this project framework the Swedish Board of Fisheries (SBF), the government agency responsible for fisheries management in Sweden, supported the formation of six comanagement initiatives dealing with different types of fisheries and involving different stakeholder groups.

The SBF, which is responsible for fisheries administration, research and development, and enforcement and control, has a tradition of consultative or advisory co-management with industry organisations at the national 
level. In the project in question the SBF should support the development of local management initiatives by supplying expertise and funds for the establishment of local organizations that could take part in fisheries management at the local level. For legal reasons the co-management arrangements could not be delegated the right to make legal decisions: Selfmanagement or informative co-management were not possible.

The project focused on the exploitation and protection of the local fish and shellfish resources. The commercial fishers were the key stakeholders in all the six co-management organisations. Other stakeholders, such as owners of water bodies and land adjacent to lakes and rivers (inland), anglers, fishing tourism, environmentalists etc., participated as active observers in some of the groups, whereas in others they were partners on a par with the commercial fishers. The SBF participated in all sub-projects, both as a facilitating partner and as the authority responsible for formulating and implementing fisheries regulation and control.

The overall conclusion from the project is that it is possible for a government agency to initiate and facilitate the creation of local organisations/groups that can co-manage local resources together with the agency. Such organizations have the possibility of identifying management needs at an early stage, exchanging knowledge among stakeholders internally and with the authorities, and developing proposals and eventually implementing them. Within the organization, possible local disagreements about the resource use and other subjects can be articulated and resolved, and mutual understanding of positions can be established.

Seen from the SBF perspective the local initiatives have offered factual knowledge, ideas and proposals that it would have been difficult to obtain otherwise. This has also included the development of new and selective fishing gear, and other self-control instruments.

Both the SBF and the various stakeholder participants, fishers and others, have realised that the co-management process is quite consuming, both in terms of money, and especially in terms of time. However, the major shortcomings relate to unsolved conflicts between local and national interests and to the lack of legal mandate in the local co-management groups.

\section{Co-management in Northern Bohuslän fisheries}

Based on previous co-management experience, a co-management group for Northern Bohuslän developed a vision and a management plan for an area 
4 miles off the Skagerrak coast. This area is morphologically diverse and rich in biodiversity. The group consisted of representatives from the local division of the national fishermen's association, the municipalities and a marine-biological research institution, with the SBF as an active observer. Other groups such as the WWF, local commercial and sport fishers' associations were affiliated, but not represented in the Steering Committee.

Part of the management plan was a so-called two-way educational programme. The one way was to educate local fishers in basic ecology, which would support the local protective initiatives. The other way was to educate researchers, managers and others in the practicalities of the local fisheries. A course in basic marine ecology was conducted with participation of 50 local fishers and funded by the project and the WWF. The training course for researchers and managers was never realised due to lack of funding.

The local group proposed to make participation in the marine ecology course a precondition for access to fishery in the area. The Swedish Fishermen's Federation (SFR) opposed this proposal at national level as it was seen as a new license system which would restrict the access of fishers from outside the region. This clash of interests between fishers at national and local levels meant that the proposal became redundant. The local group had no means to implement the proposal, and the SBF did not overrule the SFR interests at the national level.

This illustrates a problem mentioned by several stakeholder groups in the project evaluations: the mandates given to the local groups in the comanagement arrangements are not clear. The groups produce plans and proposals for local management, often after compromises have been reached between conflicting local interests. However, the groups have no formal powers to implement the plans, and no procedures are established for incorporating the plans into decision-making at higher levels. This often leads to frustration and involves the risk that some of the groups vanish as the stakeholders realise that they do not have any institutionalised platform for bringing their plans forward.

The lessons learned from this are that the mandate of co-management arrangements should be clear from the beginning of the process: 
- What kind of co-management is aimed at: consultative, cooperative or advisory?

- How will plans and proposals brought forward by the user group be dealt with in the formal management process?

- If the groups take on self-management responsibility, what are the rights, conditions and limitations?

\subsubsection{Self organisation in the blue mussel fishery in the Limfjord, Denmark}

Co-management in the blue mussel fishery in the Limfjord is a case of comanagement between self-organised fishers and the fishing authorities.

The limited blue mussel fisheries in the Limfjord developed in volume from the late 1970s. Crisis in other Limfjord fisheries lead to an increased number of blue mussel fishers, and in the beginning of the 1990s 51 fishers had obtained special licenses to fish blue mussels.

\section{Box 1: Management of the blue mussel fishery in the Limfjord 2008 catch: 26,616 tonnes. Value: 29.8 million DKK}

There are 51 personal fisheries licenses. Until now they could only be transferred to near family. From 2010 they are transferable.

Management is done by the Fisheries Directorate via announcements to license holders about gear, vessels, closed areas and periods, quotas and algae test.

The blue mussel fishery takes place in 42 sub-areas. The areas are closed until it can be documented (by water sampling) that the abundance of toxic algae is below the thresholds set and (by sampling) that the size and meat contents of the mussels are above the minimum set. The Fisheries Directorate informs about the opening of an area and the weekly quotas for each vessel.

\section{Organisation of the industry}

A local organisation of the fishers developed from the late 1970s, the Central Association of Fishers in the Limfjord (Centralforeningen for Limfjorden (CFL)). CFL members are the fishermen's associations in the fishing communities. The CFL is a member of the national Danish Fishermen's 
Association. Later the Blue Mussel Businesses Association (Foreningen Muslingeerhvervet (FME)) was formed. The association organises both the mussel processing companies and the fishermen at local and national level.

The FME plans and conducts the plantingg out of smal mussels in areas where they can grow to a commercial size and also move mussels from areas with low levels of oxygen to areas where conditions are better. Further FME organises and funds the sampling of water for the toxic algae test which is a decisive factor for the opening of the fishery in specific areas. The activities are funded through a fee on the landings, paid by the fishers and the processing industry.

Within the legal framework of the mussel fishery licenses, the CFL undertakes micro-management based on (partly) voluntary agreements between the fishers:

- The CFL can organize the closing of an area for one month when two landings from the area have contained too many undersized mussels. If the Fisheries Directorate observes too many undersized mussels in 3 landings the area will be closed for 3 months. The CFL regulation is more flexible than what the Fisheries Directorate can offer.

- Since 2006 the CFL fishers have collectively agreed to reduce their weekly landings to half of the quotas set by the Fisheries Directorate. The CFL occasionally proposes to close certain areas (or all mussel dredging) for longer periods than the official summer closure and to close some shallow water areas, due to the risks of toxic algae. In this way the CFL also tries to optimise the economic performance of its members by adjusting the volume of landings to the market situation.

- The CFL can also manage the fishing activities in order to decrease the pressure in specific areas. This is done by the drafting of fishing plans that allocate days and areas to each vessel. Such plans are forwarded to the Fisheries Directorate as advice, and they are normally followed by the Directorate.

\section{Empowering the local organisations}

The CFL has no formal powers to force the fishers to comply with the regulations decided upon by the association regarding quota reduction, area closures and allocation of fishing days and fishing areas. 
Fishing plans for each vessel are forwarded as advice to the Fisheries Directorate that normally transforms this advice into official licences for the individual vessels.

Some advice from the CFL cannot be followed by the Fisheries Directorate, among these the advice on reductions of the weekly catches. As an example the present official weekly vessel quota is 85 tonnes, whereas the CFL has decided to set a limit of 45 tonnes. The Fisheries Directorate cannot enforce this lower quota - the fishers have to comply with it on a voluntary basis. This involves, of course, the risk of free-riders, but normally (not always) this problem seems to be mitigated by the social norms.

Conflict illustrating the problem of internal justice in connection with self-organisation in fisheries management

An internal conflict in 2008 showed the limited strength of the voluntary system, but also that it gained power from the delegation of responsibility from the formal management system.

One of the minor processing companies with landings from a few vessels refused to send reports of landings to the CFL. Therefore the CFL suspected the company and the vessels of higher quota uptake than agreed on in the CFL. After some local discussions, the FME decided not to take out water samples as they normally did in order to document the level of toxic algae. No water sampling meant that the blue mussel fishery was totally closed for 8 weeks during the high season. Subsequently the company agreed to send the landing reports to the CFL, showing that they followed the quota uptake decided by the CFL.

Officially the public authorities did not interfere in the conflict. However, as no water samples were received for testing during the conflict, the authorities could not open the fishery. By being responsible for the water sampling the local self-organised associations - FME and CFL - were indirectly empowered to enforce the local management agreements on quota uptake, within the official management framework.

\subsection{Lessons learned from the Nordic countries}

There are several examples of groups of fishers or broader groups of stakeholders taking responsibility for parts of the management of specific fisher- 
ies under co-management arrangements. In the Nordic countries the role played by the POs in this respect is rather limited, but other organisations have been formed to take on such responsibilities at local level.

The Nordic cases include different types of co-management. There are consultative elements where the co-management groups comment on proposals from the authorities. However, the highest legitimacy of the regulations seems to be found where the groups also have an advisory role formal or informal. This means that proposals and recommendations are included more or less directly into the management regulations.

The co-management arrangements should define relatively clear roles and mandates. The mandate can be defined in formal terms - or informally by being demonstrated in practice. An unclear mandate can lead to frustrations as there is no institutional platform for bringing plans, ideas, proposals or comments from the groups into management decisions. The mandate should clarify the formal rights and procedures and define the "room of action" for the group in relation to possible conflicting interests at same or higher management levels.

The representativeness of the actors in the group is also very important. In the Nordic countries the national fishermen's organisations have traditionally been the natural partner in co-management. This is further increased with the growing tendency of allocating rights to clearly defined groups or individuals (as seen in the rights-based management systems). Such well-defined groups with rights and interests have the possibility of a high capacity for collective action, and thereby co- or self-management. However, as focus turns to either management at local level (with rights also to non-locals) or a broader maritime or ecosystem perspective other groups turn up as legitimate stakeholders, which questions the role of the national fishermen's organisations as the sole representatives. In the cases from Norway and Sweden the conflicting interests between fishers at local and national level within the fishermen's associations are illustrative of this. Likewise, other groups tend to get influence and a role in comanagement arrangements. This can be seen in the local groups in the Swedish case - as well as in the set-up of the RACs at the EU regional level. These conflicting interests decrease the capacity for collective action within the co-management groups.

Conflicts internally in the co-management groups have to be dealt with. The Norwegian Fishermen's Association has managed to make compro- 
mises internally between the different interests and groupings. However, the governmental management system can easily become directly involved in such conflicts, and government agencies have to decide if they actively or passively will lend authority to the groups recognized formally or informally as co-management partners as the Danish case illustrates. 


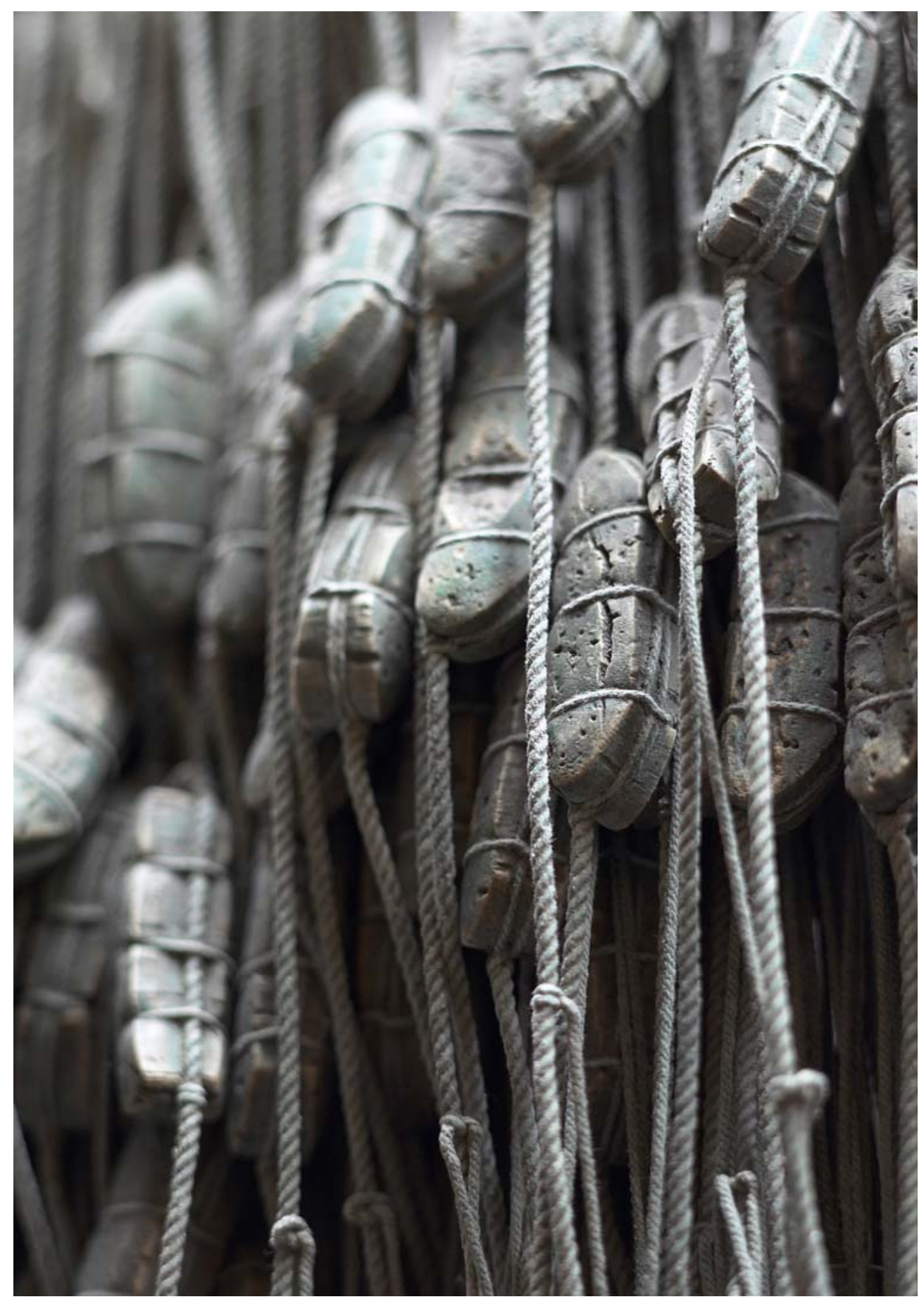




\section{Nordic experience of reduction of discards}

According to the Food and Agriculture Organization discards are the portions of fish catches that are thrown back into the sea. Discarding can have many reasons, wrong catch, wrong sizes, damaged catch, no quota or high grading. High grading means that less valuable catch or sizes are discarded in favour of bigger or more valuable fish. Discarding is a problem when the organisms returned to the sea are dead or not able to survive, because it represents both a biomass removed from the sea that is not taken into account in stock estimates and a reduction in potential future value of the discard. Discard of fish and organisms that are in a healthy condition and that are likely to survive is not regarded as a problem and is either allowed or even mandatory in some cases (for example sharks, whales, turtles) in countries with general discard bans. In this note, it is the problematic discard that is in focus.

\subsection{The Green Paper on discard}

In the Green Paper discard is seen as a problem - basically because it is waste of a precious resource which should be kept in the sea or used for human consumption. In a management context discard of by-catch and undersized fish actually seems to have prevented several stocks from recovering in spite of low quotas. This is, of course, especially a problem in mixed fisheries like a considerable part of the European fisheries. The Green Paper therefore states that "the future CFP should ensure that discarding no longer takes place” (p. 15). According to the Green Paper "new initiatives to eliminate discards and protect sensitive species and habitats" will be taken. 


\subsection{Discards in the EU}

An illustration of the discard situation could be from the North Sea, where about 3 million tonnes of fish or marine organisms are landed annually. In addition, almost 1 million tonnes of marine organisms (or about one tenth of the total biomass of fish in the North Sea) are discarded every year. 60$70 \%$ of the discards are roundfish and flatfish. However, discard is not a general problem in all North Sea fisheries. The most complicated discard problems are found in the mixed-species demersal trawl fisheries, like the flatfish beam trawl fishery, the Nephrops otter trawl fishery and the roundfish otter trawl fishery, and they are seen as responsible for most of the discards. All these three fisheries are EU managed fisheries.

In these fisheries the discard rate can be up to $90 \%$ of the volume. The estimated potential future values of the discard are calculated to be of the same size as the annual value of the targeted species. There are two fundamental causes for the high discarding in EU fisheries, namely the use of unselective fishing techniques and the failure to reduce fishing effort. The effect of both is high volumes of discards. Moreover, several important fish stocks are in a poor condition, consisting of biomasses of small and immature fish, which contributes to the discard problem.

The EU is in a process now and several initiatives are already taken, both at the federal level and in the Member States. EU has banned high grading and is also working with development of better monitoring and real-time closure systems. Fisheries Ministers around the Baltic Sea support a discard ban, but a general ban on discards is probably not realistic inside the framework of the CFP. Due to the principle of relative stability, the sharing of the TAC between member states and fisheries shall remain relatively stable. Mandatory landings, particularly if they are combined with catch quotas for fishers who do not have a share of the particular TAC, can imply a reallocation of shares and as such be in conflict with the relative stability principle.

The EU has taken several steps to solve the discarding problem: technical measures demanding the use of selective gears, or creating incentives for using it, closed areas etc., and lately also a reform of the control policy and initiatives to establish real-time closure systems for specific areas in order to avoid fishing on juveniles in the North Sea and Skagerrak. 


\subsection{Reduction of discards in the Nordic countries}

The Nordic countries have various kinds of experience with arrangements to avoid discard. However, the situation in the mixed ground fish fisheries in the North Sea is complex and experience from less mixed and complex fisheries in Nordic countries must not be seen as a formula. Nevertheless, some of the experience from the Nordic countries might be relevant.

The Nordic countries, Denmark, the Faroe Islands, Iceland and Norway have different systems of fishing regulations and various solutions to avoiding discard. It should be mentioned that the Faroe Islands, Iceland and Norway do not have huge mixed fisheries. Thus, the problem to be solved is less complex than in the EU. In addition the countries are small, with homogenous populations, and small and rather transparent fisheries sectors. The four countries all have a combination of effort regulation and output regulation (quota regulations), but the mix between them is different.

Effort and output regulations have different effects on discarding. Effort regulation, in the form of days-at-sea, is an incentive to fish as effeciently as possible. In principle, fishers will prefer not to use their limited time at sea to sort out and discard fish that they cannot sell. The motivation is to get as high a profit as possible out of the limited number of days. Effort regulation promotes selective fisheries in terms of species. On the other side effort regulation in the form of days-at-sea also promotes high catch efficiency, which means that the fishers will be interested in taking in as much fish as possible per haul and in landing as high a volume as possible. A race for fish can be the result and effort regulation can be an incentive to fish with for example as small mesh sizes as possible, with a high rate of small and juvenile fish and high grading as the result. In a pure effort regulation system the discard problem has to be addressed on the input side, through capacity regulation, fishing access, closed areas or by using technical devices. However, as the example from the Faroe Islands illustrates, a limited output control in the form of by-catch rates and an output reporting system are necessary.

Output regulations promote increase of the quota value. Thus, the fishers' interests in landing fish of the highest possible value can be a motivation for high grading towards the most valuable sizes or qualities. On the other hand, a system based on output control can address a discard problem both on the input and the output side. On the input side, discard reduction 
instruments like access, real-time closures and technical devices can be used, but since an output system is directed towards catch and quota controls, it is also possible to establish measures on by-catch and discards and require mandatory surveillance and reporting of all catch.

Independent of the type of general management system the solutions to avoiding discard can be grouped into four different types:

- Technical measures

- Regulatory measures

- Enforcement and control

- Normative elements of compliance which seem to exist in the Nordic countries.

\section{Technical measures}

The technical measures are directed towards gear selectivity, like minimum mesh size, sorting devices, minimum fish size, as well as closure of fishing grounds on a permanent or temporary basis. Sorting devices can be of different types, and for the bottom and beam trawl fisheries sorting grids of metal or plastic, or sorting net panels based on square meshes or larges

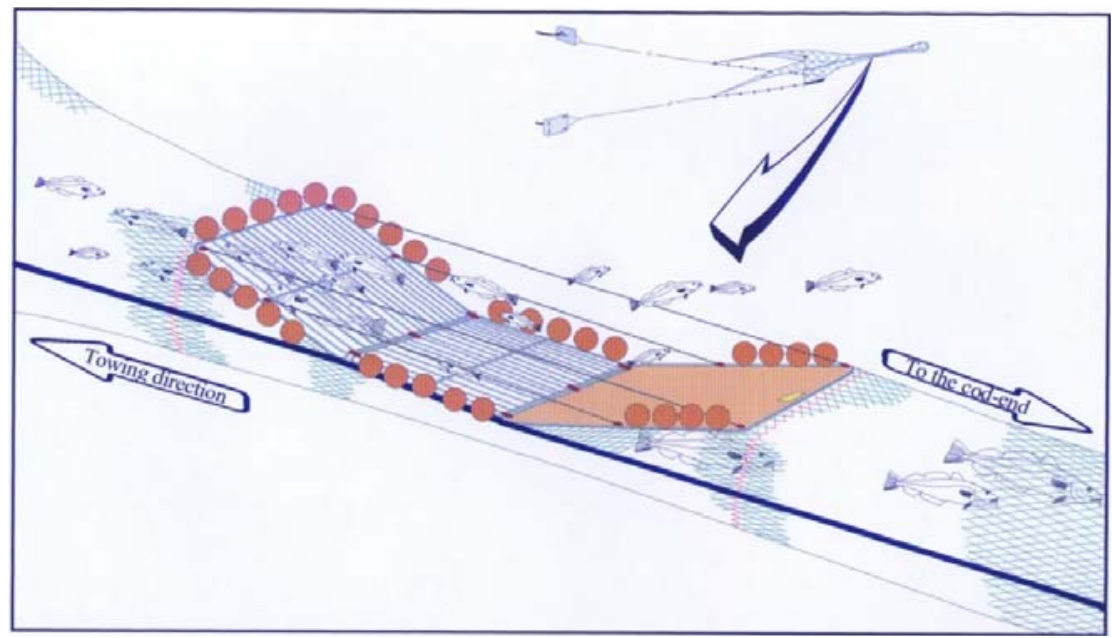

Figure 3: Sorting grid in cod trawl 
meshes, are relevant. In this regard the Nordic countries use the same type of measures as already in use in the EU, even though with varying emphasis on the specific measures. Sorting devices can be of different types. In Norwegian cod and prawn fisheries sorting grids of metal or plastic are used (Figure 3 and 4). Grids are also mandatory in the Swedish fisheries for prawn and nephrops. Fish under a certain size or species not targeted, will escape through the grid.

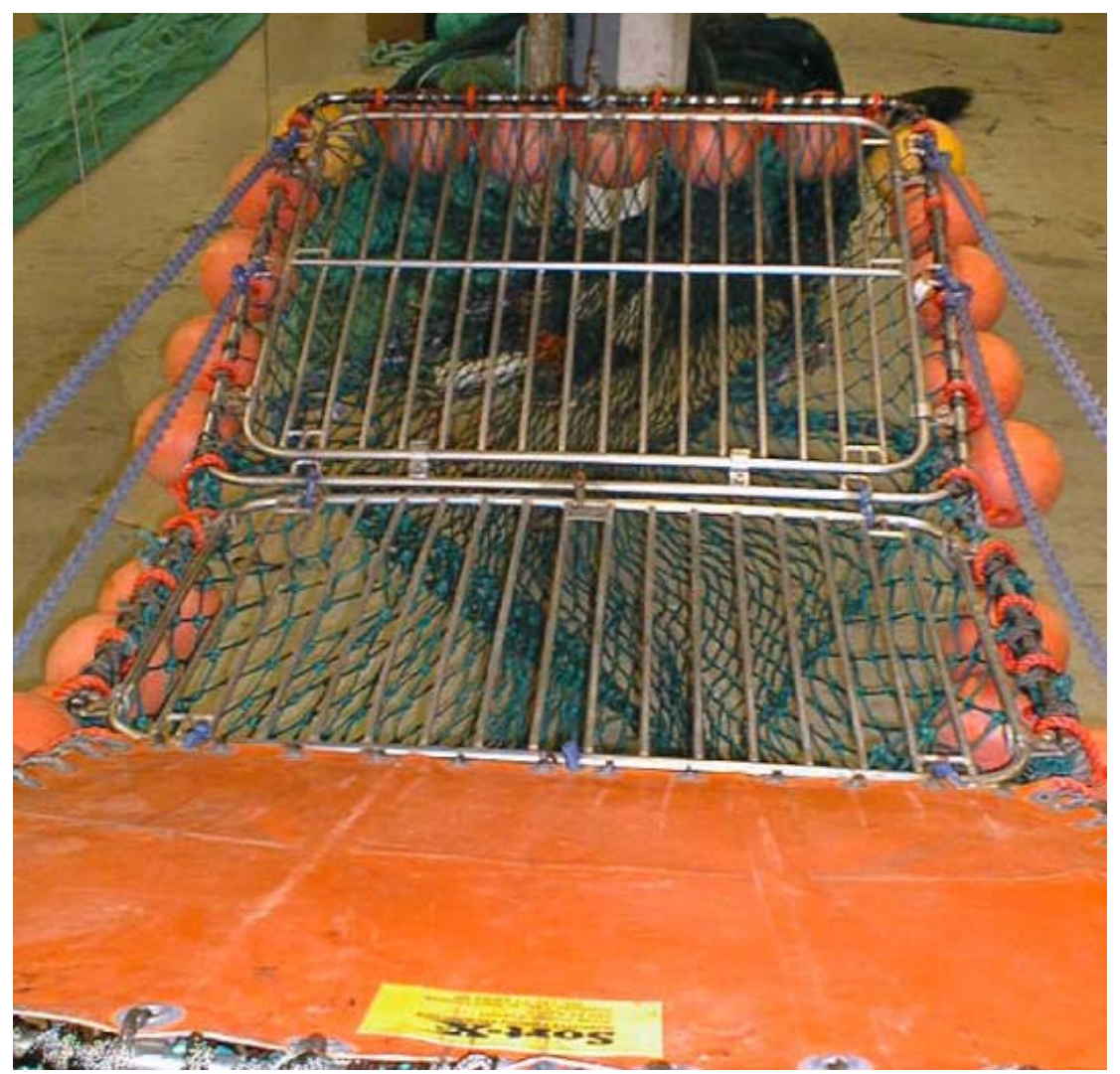

Figure 4: Trawl rogged with grid

Square mesh panels (SMPs) (Figure 5 and 6) are used to make escape windows in trawls and in purse seines. SMPs are also in use in EU fisheries. 


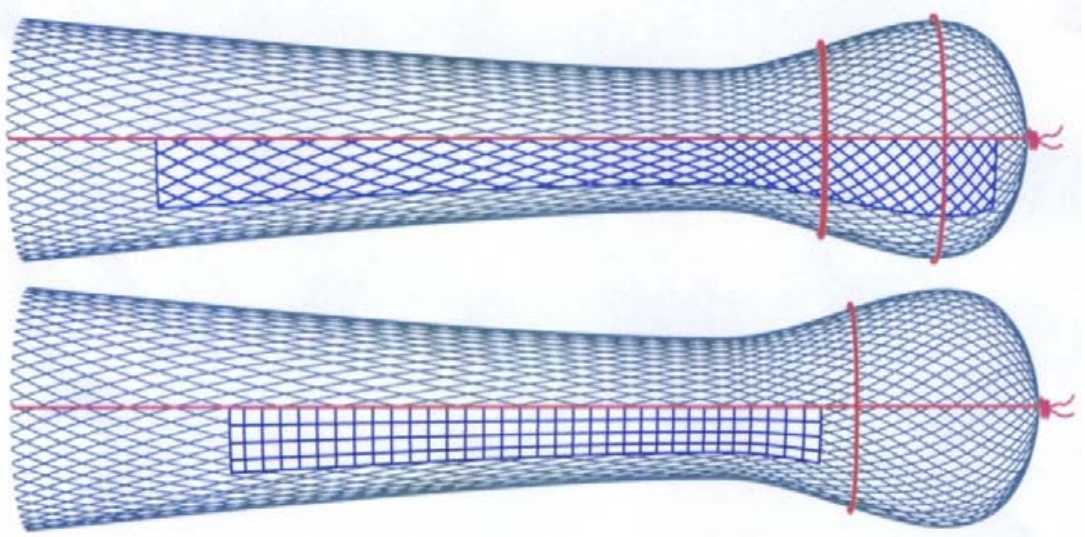

Figure 5: Sorting panels and exit windows in trawl

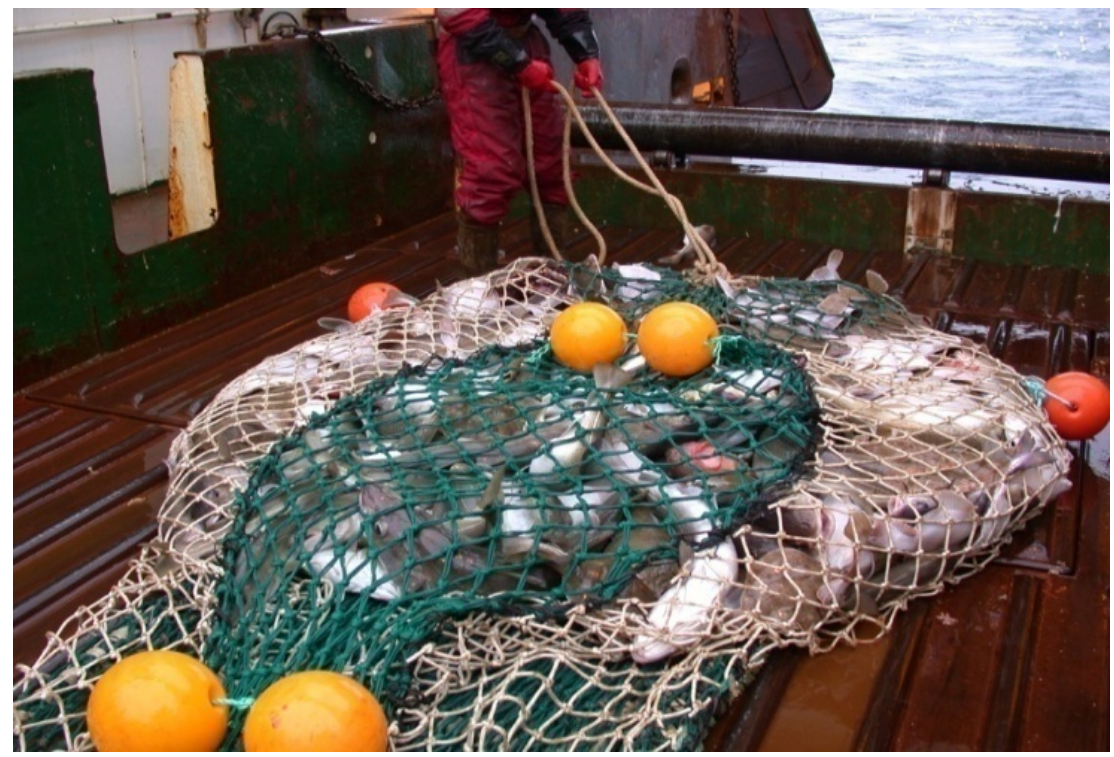

Figure 6: Exit window in trawl

Photo and source of illustrations: Roger B. Larsen, Norwegian College of Fishery Science

Particularly the sorting grids have met some resistance from fishers, and in order to motivate fishers to use grids in the Swedish nephrops fishery it has been suggested to allocate additional fishing days to fishers who voluntarily start using grids. Sorting devices have a significant effect on the amount 
of some types of by-catch, and contributes to making work easier for the fishers.

\section{Regulatory measures}

The regulatory measures deal with ban on discard, mandatory landings, output and effort control through by-catch quotas or shares and monitoring.

- Mandatory landings

- Catch log recording and control

- Landing reports and control

- Inspections at sea

- Monitoring of fishing grounds

- By-catch rules.

\section{Mandatory landings}

In terms of regulatory measures, the main difference between the EU and the Faroe Islands, Norway and Iceland is mandatory landings. In principle discard is illegal in all these three countries, and the total catch has to be landed. To a great extent the fishers in the respective countries are in favour of mandatory landings, as long as the fishing authorities are willing to accept pragmatic adaptations when it is required. In practice, however, non commercial species and fish of certain other species that are alive will be discarded. Contrary to this, the EU fishers are obliged to discard. The ban on discard in the Faroe Islands, Norway and Island, combined with a sanction system, makes it possible to prosecute those who do not comply with the law. On the other hand, the fact that the fishers are allowed to sell bycatch represents an economic incentive for the fishers to land their catch. The economic incentive and the opportunity of landing valuable fish makes it irrational to discard such fish. However, discard ban and by-catch rules do not necessarily prevent high grading. In Iceland and Norway, having individual quota systems, the fishers will be interested in maximising the value of their quotas, which under certain circumstances can motivate them to high grade, both the main targeted species and species caught as bycatch. The obligation and the incentives to land and sell can, in combination with a quota system where all catch is deducted from a quota, be a motivation for high grading. $100 \%$ control is impossible, and in the end the 
success of the system depends on the fishers' willingness to comply. Thus, the legal measures may be seen as necessary, but not sufficient.

Catch log recording and control, landing reports and control and inspection at sea

The Faroe Islands, Iceland and Norway have Monitoring, Control and Surveillance (MCS) systems, based partly on document control of catch log and landing reports and partly on inspections of the actual practices on land and at sea. The effectiveness of a MCS system depends partly upon the economic, material and human resources available, the organisation of the system, the power and competence of the system and the institutional and legal framework it operates within. No comprehensive comparisons of MCS in the EU and the Nordic countries are available, and therefore it is not possible to compare the various MCS systems. Due to both Illegal, Unregulated and Unreported (IUU) fishing and bi- and multilateral collaboration on fisheries management there are contact and collaboration about these issues across national borders.

Monitoring of fishing and fishing grounds in combination with real-time closure of fishing

The Faroe Islands, Iceland and Norway have extensive monitoring of fishing and fishing grounds. The monitoring is partly conducted by the fishers themselves, since they are responsible for reporting for example too high a biomass of juveniles in an area, partly by inspectors onboard fishing vessels and finally by special surveys. The monitoring is the basis for realtime closures of areas. The fishers are responsible both for reporting and for actively changing fishing ground if the fishing cannot be undertaken without too high rates of juveniles, even before the ground is formally closed. Intentional or negligent violation of the rules by the fishers can result in legal action.

\section{By-catch rules}

By-catch rules is a measure that makes it possible to undertake fishing, even if the targeted species is mixed with other species. In the Nordic countries the fishers are allowed to have certain rates of other species in their catches and to land amounts of fish equivalent to those rates. How these rates are calculated - haul, day or trip - depends on the fishery, but 
the central instrument for control in this respect is the catch log. Normally the by-catch can be sold either to the benefit of the fishers or for a collective purpose. If the by-catch rules are broken by coincidence, without intention or negligence from the fishers, then the catch shall be landed, but without consequences for the fishers. However, in such a situation the value of the illegal fish will not go to the fishers.

\section{Responsibility}

Even if the fisheries are strongly regulated, the fishers at sea have the opportunity to cheat. Breaches of the rules are not uncommon, but there are no indications that cheating is a widespread practice.

This may be a result of collaboration between fishers, scientists and managers. The fishermen's organisations in the three Nordic countries have been involved in management for a long time, they are used to communicating with managers and scientists, and they exchange experience and values. Even if there are still tensions and conflicts between fishers and managers, we might see a development towards a common rational platform between fishers and managers.

Further the fishers are not a representative group of citizens. As a consequence of the structural changes in Faroese, Icelandic and Norwegian fisheries fishing is undertaken by a declining group of more and more professionalised people, with many common interests. There is reason to believe that they have to some extent developed a common code of conduct. This code, however, can both result in a high level of compliance when the rules are regarded as rational and legitimate, but can also be the reason why some fishers do not report when they see others violating the rules.

The size and the transparency of the sectors in the three countries may also have some impact. It is not easy to cheat when everybody knows the size of your quota or the days-at-sea.

Finally the fact that the fishers themselves are responsible for a proper conduct and that they have to prove this conduct through a system of recording and reporting may over time also result in an increased responsibility. To some extent, the system for recording and reporting place the burden of proof for responsible behaviour and conduct on the fisher and not on the system. 


\section{Certification programmes}

Both in Iceland and Norway processes of certification of sustainable fisheries have started. These processes increase the fishers' responsibilities. Since the processes are in an initial or early phase it is too early to draw conclusions, but the ability to avoid or reduce discard may in the future be one of the criteria for certification. Fisheries that are not able to attain certification may experience that they both loose fishing rights and market shares.

\subsubsection{The Faroe Islands - effort regulation in mixed fisheries}

The Faroe Islands' demersal fishery is a mixed fishery for cod, saithe and haddock. Until 1987 the Faroe Islands had no regulatory means to limit catch quantities in demersal fisheries. In 1994 a TAC/ITQ system was created, and like Norway, the Faroe Islands banned discard. This TACbased system was in 1996 abandoned, partly because of the costs and administrative capacity needed in connection with this form of management, and partly because it was assumed that illegal landings and discards were undertaken.

The TAC/ITQ system was replaced by a system of effort regulation, based on fishing days allocated to licence holders. A number of fishing days is allotted to the licence holders annually, based on the estimated capacity for each group. Through different measures the capacity is controlled. Capacity control is crucial for the fishing-day system since an increase in the capture capacity will lead to an increase in the effort per fishing day.

At the same time the ban on discards continued together with closed areas, minimum fish size regulations and mesh size regulations to protect juvenile fish. All other output regulations were dropped.

The small-fish regulations allow the vessels to fish a certain share of fish under the minimum size per haul, for example 30\% cod sized under 55 $\mathrm{cm}$ per haul. The fishermen are obliged to immediately report big hauls of juvenile fish to the Fisheries Inspection that can close the area. In addition, the fishermen are held responsible for not exceeding a trip limit of $5 \%$ cod under $40 \mathrm{~cm}$.

The fishing-day system is simple in terms of legislation, administration and enforcement, but requires a good control of capacity expansion and monitoring of the vessels. Larger vessels (over 15 tonnes) must have a 
vessel monitoring system (VMS) installed, while smaller vessels are monitored through landing tickets.

\subsubsection{Iceland - ITQs, effort and catch quotas in combination}

Iceland was an early European frontrunner in terms of introducing ITQs in the fisheries. Quotas were introduced in Iceland in the mid 1970s, a system that later developed into an ITQ system to ensure economic efficiency. More information about the Icelandic system can be found in chapter 2 .

Iceland has a system for monitoring and controlling individual vessels. Landed catch is weighed by accredited harbour officials and registered in the central database in the Directorate of Fisheries. According to a legal mandate, the catch and quota use is published through the website of the Directorate of Fisheries in order to ensure transparency.

The vessels are obliged to fill in detailed catch logs with information about fishing area, catch composition, and quantities. Landing of the catch is monitored by inspectors from the Directorate of Fisheries, who also have access to the vessels' catch log. If the inspections demonstrate that the catches contain too many small fish, the actual fishing grounds can be closed. Moreover the Icelandic Coastguard monitors and inspects the vessels operating in Icelandic waters.

To ensure that catch information is reliable, buyers and sellers of catches are obliged to report to the Directorate of Fisheries. The Directorate can react against discrepancies, and if the management legislation is violated, the law breakers are subject to fines, revoking of fishing license or in some cases imprisonment. The responsibility for a proper conduct is placed on the fishermen, who are responsible for ensuring that they have quotas for the respective species they fish and land. In order to stop discards there is a general discard prohibition clause.

If a vessel overfishes or gets huge amounts of by-catch, the company has the option to obtain additional quota within a certain period of time after landing. Thus, the fishermen have an incentive to land all the fish they catch. In addition it is allowed to land a by-catch percentage without using quota. This amount of fish will be sold at an auction for the benefit of a research fund. 


\subsubsection{Norway - mandatory landings and catch quotas}

Since the late 1980s the most important Norwegian fisheries have been regulated through a system of licences and quotas in combination. In addition a complex and detailed system exists for discard control, based on output control, ban on discard, a variety of technical regulations, and pragmatic adaptations. In principle all discards are prohibited. However, exceptions are made for certain species like shellfish, crustaceans, starfish, sponges etc., and fish and other marine organisms that are alive and can survive. In addition closed areas are used for habitat and juvenile protection.

In practice the ban on discard means that if a vessel has a quota for a certain species, for example cod, by-catch of cod in other fisheries will be deducted from the ordinary vessel quota. If the vessel has already used its cod quota, it will have to stop fishing for other species if there is a risk that cod can be taken as by-catch. It is the skipper's responsibility to ensure that the vessel has quotas to participate in the respective fisheries.

Unlike in Iceland, it is not possible to buy additional quotas after the catch is landed. If a vessel does not have an ordinary quota of a species, it is common to allow a certain percentage of the species as by-catch. The percentage differs from fishery to fishery, with specific rules about bycatch per haul and per trip. If the by-catch rate is too high the fishermen are obliged to change fishing ground. Direct fishing on banned species or sizes is under all circumstances unjustifiable. Illegal fish (exceeding the allowed percentage or the vessel's quota) that is landed is sold by the Sales Organisation. If the fish is caught unintentionally, and reported and landed in a legal way no further action is taken. Legal action can be taken, if it can be proved that the fish is caught on purpose or not reported.

Vessels larger than $15 \mathrm{~m}$ are obliged to keep catch logs. Every haul must be recorded immediately with data about fishing ground, species caught and estimate of quantity. The skipper is responsible for an accurate recording of the catch, and the estimates should not deviate more than $10 \%$ from the actual quantity landed. The log can be checked both through landing control by inspectors from the Fisheries Directorate and through inspections at sea by the Coast Guard.

Moreover the landed catch is reported by the buyer to the Sales Organisation and checked against the fishing rights of the vessel. This control is performed by the Sales Organisation and the Fisheries Directorate. Finally, 
the Fisheries Directorate can perform physical inspection of landings, sales and export.

In the herring purse seine fishery, seine bursting because of too much fish in the seine can be a problem when fishing in daylight. Therefore day-time closures are used as a means of regulation if this problem is reported frequently. The fishers are responsible both for trying to estimate the size of the shoal before they set the seine, and for reporting if the seine bursts. This is an example of how regulations are adapted to different fish behaviour.

To protect juveniles and undersized fish, the Fisheries Directorate continuously monitors fishing grounds to introduce real-time closures when needed. The monitoring is based on risk assessments in different fisheries and is undertaken both by chartered vessels doing surveys in areas where the risk of undersized fish is high, as well as by inspectors onboard ordinary vessels. Several projects are undertaken to develop electronic systems for reporting and surveillance, and for vessels over $24 \mathrm{~m}$ satellite transponders for Vessel Monitoring Systems are mandatory.

\subsubsection{Denmark - quota swap and full video monitoring and catch quotas as incentive}

Denmark manages discards in accordance with the EU regulations, meaning that fishers are obliged to discard catches for which they do not hold quotas. In 2007 the introduction of transferable vessel quotas (VTQ) gave the fishers quotas on a yearly basis (instead of on a 2-weekly basis), and at the same time they got the possibility of buying, renting or swapping additional quota (this is described in chapter 2). This gave the fisher the opportunity to plan the fishery according to his own quotas, or to calculate with bought or rented quotas. The adjustment can take place even after the fish is caught. The transferability of quotas is limited to some extent, but if the fisher joins a so-called quota pool the exchange is quite easy. Two thirds of the VTQ vessels have joined one of the quota pools, of which there is a handful in total. This indicates an interest in obtaining flexibility with regard to quota utilization and reduction of quota-related discard.

However, some quota-related discard is left, as well as the incentive to high grade. The Danish Ministry of Food has launched a project regarding full video monitoring. Six vessels accepted to have four video cameras and other electronic surveillance equipment installed so that catches and dis- 
cards could be monitored very precisely - the project indicates that a good video monitoring is possible. The vessels were obliged to register all catches and discards. All catches of quota fish were counted against the individual quota, and the fishers were only allowed to discard fish under the minimum size. In return for their participation the vessels got extra quotas. But why should the fishers accept such surveillance and incur losses in consequence of not being able to high grade and having to count all catches against their quotas? The Danish proposal is radical: Give the fishers who accept the monitoring an incentive - the so-called catch quota. The catch quotas include (a part of) the amount of fish, which in the ordinary TAC setting process is set aside for discard. The documenting fisher gets a higher quota since the counting of all catches against the individual/vessel quota is an important incentive to avoid discard. As all catches are registered when they come on-board, the fisher will only discard fish that cannot be sold.

\subsection{Lessons learned from the Nordic countries}

The fisheries systems in the Nordic countries apply a mix of effort and quota regulations as their main principles for regulating fisheries. The Faroe Islands have a rather pure fishing-days system, while Denmark as the rest of the EU has a mix of quota and days-at-sea regulation. In Iceland they have mainly based their system on ITQs, while Norway has an individual quota system with only limited transferability. Independent of the main system for fisheries regulations, the Faroe Islands, Iceland, and Norway have specific measures and procedures to avoid discard. All the three countries have bans on discard, combined with rather sophisticated systems for control and enforcement with legal mandates to act if the rules are violated. To some extent the success of the "discard policy', which is actually difficult to evaluate since there is no means for a total control at sea, depends on how legitimate and rational the fishers regard the system to be, and whether they see the reasoning behind it.

The fishermen in the three countries have economic benefits from landing legal by-catch. This is an important aspect. In the Faroe Islands and Norway the fishermen get paid for this catch, while in Iceland the catch is sold to the benefit of a research fund. In addition, the fishermen have the 
option to buy quota after landing. In both cases, discard will represent an economic loss for the Icelandic fishers.

Finally, the systems in the Faroe Islands, Iceland and Norway place a huge responsibility on the fishermen for complying with the rules. The level of compliance is assumed to be high, partly because the system is well-known and fairly transparent, which makes it complicated and risky to break the rules, and partly because the system is considered reasonable and legitimate by the fishermen. This is due to the extensive influence and participation that fishermen in the Faroe Islands, Iceland and Norway traditionally have had in the design of the respective countries' management systems. Critics might claim that since there is very little control on the boats this can be difficult to evaluate.

Table 3: Measures with regard to discards

\begin{tabular}{lllll} 
& Denmark & Faroe Islands & Iceland & Norway \\
\hline Ban on discard & No & Yes & Yes & Yes \\
Closed areas & Yes & Yes & Yes & Yes \\
Real-time closures & Yes & Yes & Yes & Yes \\
Sorting devices & Yes & Yes & Yes & Yes \\
Gear selectivity & Yes & Yes & Yes & Yes \\
Economic incen- & Additional quota & By-catch value & Additional quota & By-catch value \\
tives & can be bought & & & Licence \\
Effort regulation & Fishing days/ & Fishing days/ & Licence & \\
& licence & licence & & Yes \\
\hline
\end{tabular}

The most important Nordic experience with regard to discard is the ban of discard, which is seen in the non-EU member states: Iceland, the Faroe Islands and Norway. This could be a way forward for the EU fisheries policy as well. The Nordic experience is, however, that a ban has to be backed by rules and regulations, and economic incentives to avoid discard.

The three above-mentioned Nordic countries have developed sophisticated systems for control and enforcement with legal mandate to act if the rules are violated. It is, however, impossible to totally avoid by-catch, and therefore mechanisms have been developed which reduce the economic incentive to discard catch of undersized or just small fish. 
There is no ban on discard in Denmark. But the shift to a system of vessel transferable quotas with yearly quotas and the possibility of buying supplementary quota has diminished the need for quota-related discard considerably.

In Denmark another approach of full monitoring of catches by video cameras has been tested. This seems to allow the fishermen to document their catch - and discard - through a very detailed monitoring. Such surveillance systems can only function if the fishers are fully supportive them on a voluntary basis. In this regard the use of the so-called "catch quotas" seems to be a very interesting incentive for the fishers who are willing to take full responsibility for documenting their actual catches and thereby also discards.

If it is impossible to introduce a catch quota for by-catch because of the more general system in the EU, based on relative stability, the Icelandic solution with sales of mandatorily landed by-catch to the benefit of a research fund should be looked into. The grants from the fund could be aimed at research in selective fishing gears and methods, discard reduction, and/or fishing ground monitoring, and consequently benefit all fishers.

In any case a further development of technical measures and a combination of the measures, depending on the specific fishery, are important tools. Measures as new selective gear, science-based closed areas or temporarily closed areas on a voluntary basis will be important tools with a view to reducing discard - both in connection with management regulations and in support of fishers' endeavours to avoid discard.

The discard problem can obviously not be solved only through system designs. Steps must be taken to increase the fishers' responsibilities. Participation, both in the design of the system and in decision-making, is important. Increased responsibility for monitoring of stocks and grounds, and certification schemes for sustainable fishing seem to be elements that become more prominent in the Nordic countries. To be labelled a responsible fishery and responsible fishers may be more important in the future, and it will be in the interest of the fishers to attain such certification. 


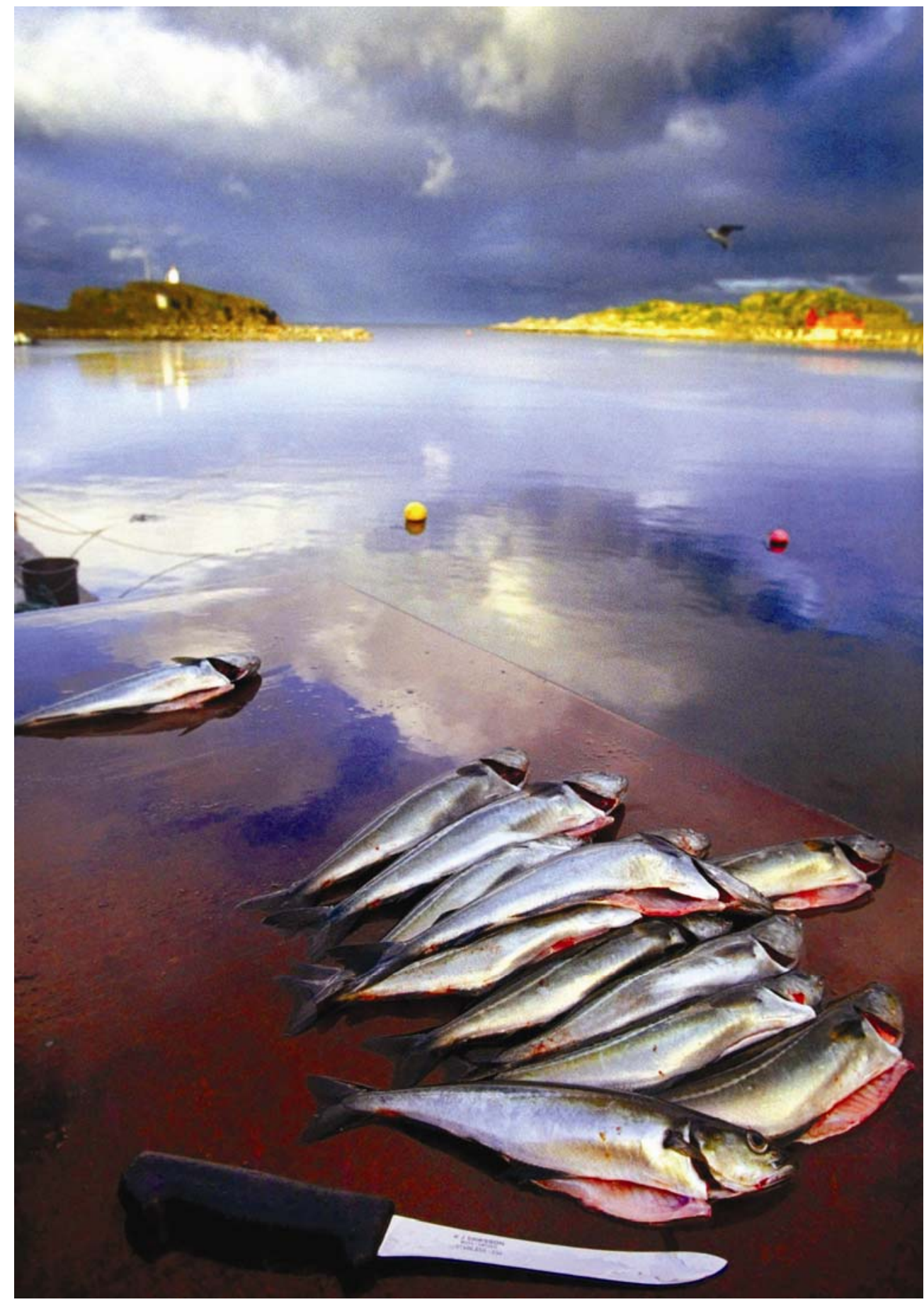




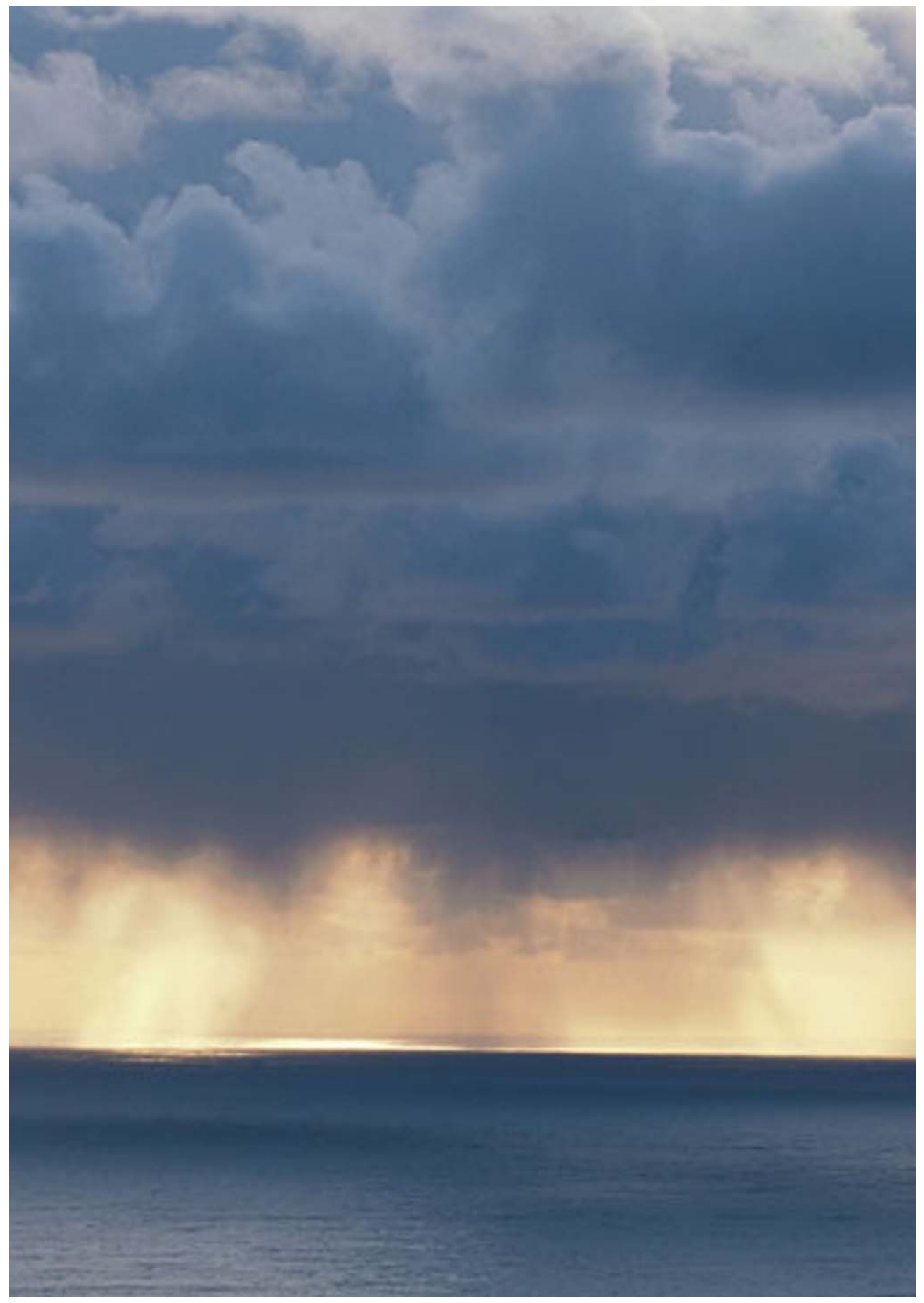




\section{Conclusions}

The intention of this note is to bring Nordic experience into the discussion of the reform of the Common Fisheries Policy. The themes and cases presented address issues which feature prominently in the Green Paper: reduction of over-capacity by establishing rights-based management systems, increase of responsibility in the industry through development of comanagement arrangements, and reduction of the discard of fish.

The examples have been examined in order to try to identify solutions that may be pertinent to the reform process. There are certainly lessons to be learned from the Nordic fisheries in regard to the discussion of the reform of the CFP. However, it is important to note that no model can be transferred directly from one setting to another - which the variations between the Nordic countries clearly demonstrate. In the discussion of the Nordic experience in relation to the CPF reform, their specific contexts must be kept in mind. What are the social, political and ecological circumstances under which the Nordic solutions and models have been developed? In which ways are they similar to or different from the situation in the EU? How should Nordic models be modified in order to provide solutions to the CFP?

\subsection{Rights-based management}

In the Nordic countries RBM systems with transferability of rights have contributed to adjusting the fleet capacity to the fish resources available for exploitation. This is the common experience from Iceland, Norway and Denmark, despite the differences in sector structure and resource base. With the reduction of the fleet capacity to match the TACs and fish quotas, the economic performance of the remaining active fishing vessels has im- 
proved significantly. The fishing industry in the Nordic countries has become more profitable with the adoption of RBM systems, generating a sizeable resource rent. The experience from the introduction of RBM systems also demonstrates that such policy decisions are very sensitive Adaptive bottom-up approaches involving the stakeholders in the system design have shown to generate lasting solutions, whereas inflexible top-down approaches have largely failed do to lack of legitimacy with the industry

The Green Paper raises the question if the CFP should adopt a "two tier" management regime: one for the large-scale fleets where capacity adjustment and economic efficiency is at the core, and another for the small-scale fleets in coastal communities with a focus on social objectives. In the Nordic countries, this dichotomy has been taken into consideration, and the RBM systems adopted have been designed accordingly. The experience are that, even if ITQ/VTQ systems are particularly suited to cater for capacity adaptation and economic efficiency, they can also be designed to cater for social concerns related to small-scale fisheries and coastal communities. This can either be achieved through a special "coastal fisheries" scheme giving special rights (and obligations) as implemented in Denmark, or through restrictions on the quota allocation and the transfer of quotas between vessel segments and/or geographical areas as practiced in Norway and Iceland. Closely associated with the concern for the livelihood of coastal communities is the concern for new (particularly young) entrants to the fishery. This is in particular about meeting the increasing costs of investments, associated with most RBM systems, in both material assets (vessel and fishing gear) and immaterial assets (fish quotas). This concern has also been addressed in the design of the systems adopted in the Nordic countries.

The Nordic experience shows that the introduction of RBM systems is highly sensitive, despite 'obvious advantages' in terms of economic efficiency etc. This relates not only to the perceptions of the impacts of such management systems on fishing communities and sector employment, but also to the principles applied for the allocation of fishing rights and the distribution of the associated wealth. The lesson learned from the Nordic experience is that the introduction of RBM should be adaptive and with an open discussion among all stakeholders about features and impacts of the system, both in relation to policies and development within the sector, and in relation to policies and development in the society at large. 


\subsection{Co-management}

The Nordic countries show several examples of groups of fishers or broader groups of stakeholders taking responsibility for parts of the management of specific fisheries under a co-management arrangement. The cases presented include different types of co-management. There are many consultative elements where the co-management groups comment on proposals from the authorities. However, the highest level of legitimacy of regulations and compliance are found where the groups also have an advisory role, formal or informal, so that their proposals and recommendations are included in the management regulations.

The Nordic cases illustrate conflicting interests between fisher groups at local and national level and other groups seeking to get influence and a role in co-management arrangements. The cases illustrate that internal conflicts in the co-management groups are not uncommon, and that they sometimes reduce the capacity of the group to influence decision-making. Nevertheless, the Nordic cases illustrate that it is possible for stakeholder groups to take responsibility and reach compromises, also when conflict levels are high. An important lesson in this context is that governmental agencies easily get involved in such group conflicts, and thus that the decision to lend authority to stakeholder groups, formally or informally, should be considered carefully.

\subsection{Discards}

The fisheries systems in the Nordic countries apply a ix of effort and quota regulations as the main principle for regulating the fisheries. In the Faroe Islands the system is based on fishing-days, while Denmark uses a mix of quota and days-at-sea regulation. Iceland has mainly based their system on ITQs, whereas Norway practices an individual quota system with limited transferability.

The Faroe Islands, Iceland, and Norway all have implemented a ban on discards, combined with systems for control and enforcement and including strict interventions when the rules are violated. The fishers in these countries benefit economically from the landing of legal by-catch, and they are also allowed to buy quotas after landing. In both cases, discard would 
othervise represent an economic loss. The systems in the Faroe Islands, Iceland and Norway place a significant responsibility on the fishers. The compliance seems to be high because the ban and the repercussions are well-known. If you break the rules it is at the risk of getting exposed. In addition, the management of discard is considered reasonable and legitimate by the fishermen, due to the extensive influence and participation that fishermen in the Faroe Islands, Iceland and Norway traditionally have had in the design of the respective countries' management systems.

The Nordic experience with regard to ban on discards could be a way forward for the EU as well. The experience is, however, that a ban has to be backed both by reasonable rules and regulations and by economic incentives. It is impossible to totally avoid by-catch, and therefore mechanisms have been developed to discourage the discard of undersized or just small fish. The Icelandic solution with sale of mandatorily landed by-catch for the benefit of a research fund is promising. The grants from such a fund could be aimed at research in selective fishing gears and methods, discard reduction and/or fishing ground monitoring, and in that way it could benefit all fishers.

A new Danish approach implemented on a pilot scale works in another direction - higher catch quotas to those fishers who document and register all their catches including discards. This system requires the fishers to provide documentation in the form of full video monitoring of all their catches in return for a quota taken from what is normally set aside for discard. The acceptance of this approach among fishers and in the political system is still to be seen.

\subsection{Linking RBM, co-management and discard policies}

The three main themes, RBM, co-management and discards, have been treated separately, but there are important relationships between them.

There is a strong relationship between rights-based management models and co-management. Rights-based management, at least in the form of ITQs, and co-management are sometimes presented as contrasting and incompatible models. This is, however, not always the case. On the contrary, the establishment of stronger rights, tied to social groups with clearly defined membership, usually improves the capacity for collective action 
within such groups. In addition to their consequences for the individual rights holder, the introduction of RBM models often leads to improved capacity for stakeholder group involvement. In other words: RBM models may improve the possibilities for strong co-management and active user group participation in management. This effect should be taken into consideration in the design and implementation of RBM systems.

The examples presented have also showed that RBM systems and comanagement are highly relevant with regard to reduction of discards.

First, it has been demonstrated how RBM models may constitute an important, partial solution to the discard problem. As the Icelandic case shows, quota trading, carefully designed with regard to the specifics of the fishery at hand, is a flexible mechanism for adapting a vessel's quota portfolio to actual catches. In this way, quotas are distributed over the fleet in a way that reduces the discard problem.

Second, it has been shown how co-management models may provide an effective approach to the discard problem. In the Danish example, there are ways to make stakeholder groups responsible with regard to discards. Here, effective surveillance is combined with incentives and user autonomy in such a way that it becomes in the fishermen's own interest to solve the discard problem.

In general terms the Nordic experience shows the potential, as suggested by the CFP Green Paper, of intoducing increased delegation, in the form of rights-based and co-management solutions, to solve entrenched problems. If the appropriate framework is provided, stakeholder groups show great capacity for taking on the responsibility for solving complex management problems. 


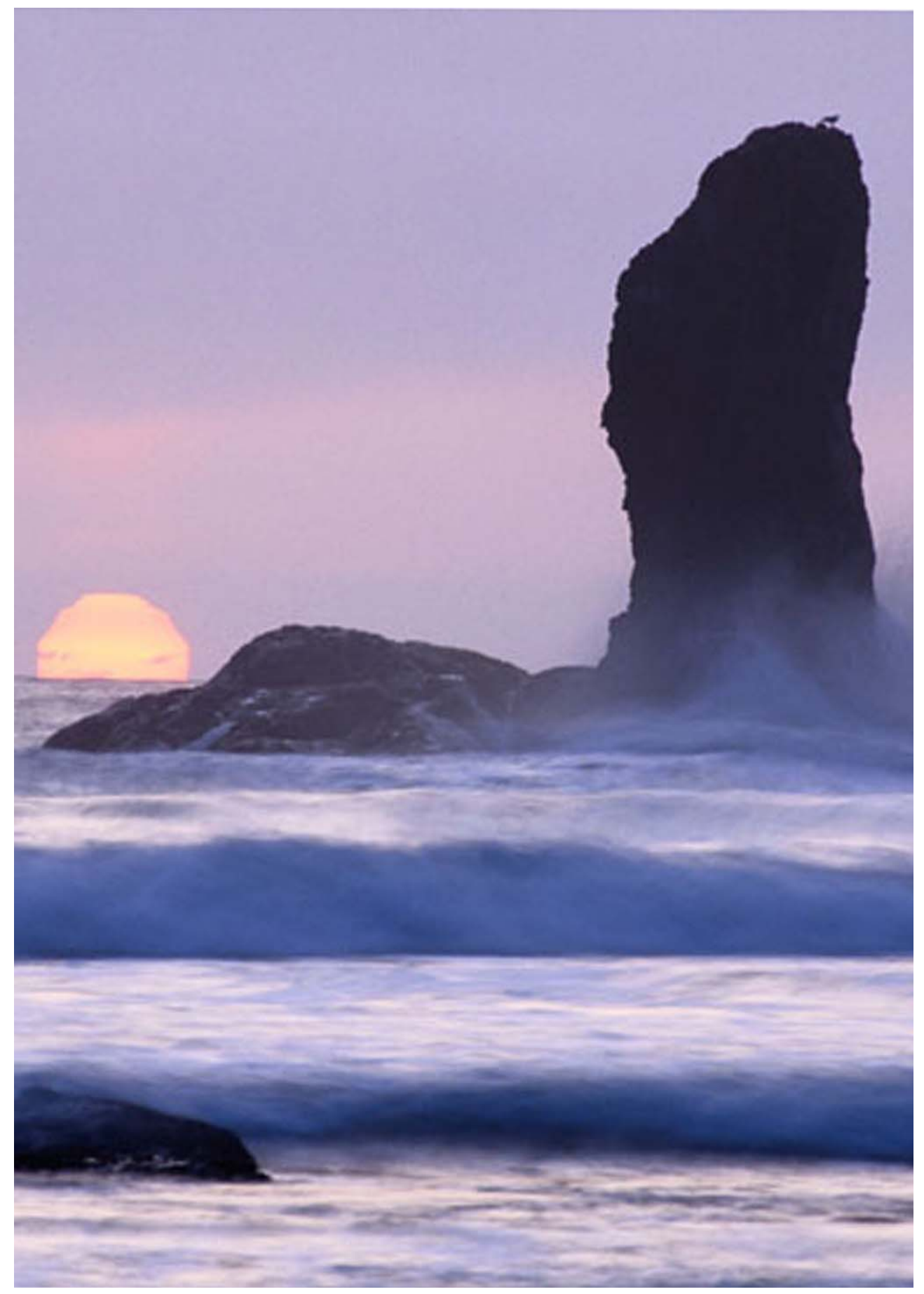




\section{Sammenfatning}

Formålet med denne rapport er at inddrage de nordiske landes erfaringer i diskussionen om reformen af den fælles fiskeripolitik. Diskussionen tager afsæt i Kommissionens grønbog som indeholder en sammenfatning af status for fiskeriet i EU og som tager temaer og spørgsmål op til diskussion. Temaerne og de konkrete cases i denne skrivelse vedrører emner som får stor opmærksomhed i grønbogen: reduktion af overkapacitet via etablering af rettighedsbaserede forvaltningssystemer, forøgelse af industriens ansvar via udviklingen af medforvaltningsordninger samt en reduktion af discard af fisk.

Havene omkring de nordiske lande er rige på fiskeresurser. Indtil nu har fiskeriet været blandt de vigtigste produktionssektorer i de nordiske økonomier, og på Færøerne og i Grønland er fiskeriet den klart vigtigste sektor. Forvaltningen af fiskeriet har gennem tiden haft forskellige formål i de nordiske lande, lige fra fiskale og sociale formål til bevaring af bestande samt socio-økonomisk trivsel de seneste år. Der er store ligheder mellem de nordiske lande, men forskellene i økosystemerne og de socio-kulturelle vilkår for fiskerierne har alligevel medført forskellige forvaltningssystemer.

De nordiske erfaringer i forbindelse med flådereduktion ved hjælp af rettighedsbaserede forvaltningssystemer (RBM) viser at:

- Introduktionen af RBM, som gør det muligt at overdrage rettigheder, har medvirket til at flådekapaciteten er blevet tilpasset de fiskeresurser som er tilgængelige for udnyttelse.

- Med reduktionen af flådekapaciteten således at den passer til TAC og fiskekvoterne, er de økonomiske resultater for de resterende aktive nordiske fiskefartøjer væsentligt forbedret inden for alle flådesegmenter - også selv om gælden er steget. 
RBM har også andre implikationer som kan forklares med den måde hvorpå systemerne er konstrueret:

- RBM-systemer kan konstrueres til at tilfredsstille de sociale interesser i forbindelse med fiskeri i lille skala og i kystsamfund via særlige planer for kystfiskeri eller restriktioner i forhold til fordelingen og transporten mellem regioner og/eller geografiske områder.

- Et andet forhold, som i nogle af de nordiske lande er blevet forklaret med måden hvorpå systemerne er konstrueret, er problemet med stigende udgifter til investeringer for nye fiskere.

- Særlige kvotefonde for nye fiskere kan reducere forhindringerne i opstartsfasen som følge af de stigende udgifter til investeringer i fiskeriet. Dette er især vigtigt med henblik på at sikre kystsamfundenes overlevelse.

Introduktionen af RBM-systemer er i høj grad et ømtåleligt emne. På trods af fordelene hvad angår den økonomiske effektivitet etc. er der bekymring over konsekvenserne for fiskersamfundene og beskæftigelsen i sektoren, men også over de anvendte principper i forhold til fordelingen af fiskerettigheder og fordelingen af den rigdom som er forbundet hermed. Erfaringen fra Norden er at introduktionen af RBM skal tilpasses og inkludere en åben debat med deltagelse af alle interessenter om systemets karakteristika i forhold til de politiske mål i fiskeriet og i samfundet generelt.

Grønbogen sigter mod at skabe ansvarlighed i industrien for den fælles fiskeripolitik. Medforvaltning eller selvforvaltning anses for at være værktøjer med henblik på at opnå dette. Der findes adskillige nordiske eksempler på grupper af fiskere eller bredere grupper af interessenter som tager ansvar for dele af forvaltningen af specifikke fiskerier under medforvaltningsordninger med rådgivende organer.

- Den højeste grad af legitimitet i bestemmelserne findes når grupperne også har en formel eller uformel rådgivende rolle, og deres forslag og anbefalinger mere eller mindre direkte inkluderes i forvaltningsbestemmelserne.

Medforvaltningsordningerne bringer de potentielt modstridende interesser, som kan eksistere mellem fiskere på lokalt og nationalt niveau og andre 
grupper som søger indflydelse i medforvaltningsordningerne, frem i lyset (præcis som man har set i forbindelse med etableringen af RAC'er på regionalt EU-niveau). De konkrete cases illustrerer at:

- Store interne konflikter i medforvaltningsgrupperne nogle gange kan reducere deres evne til at påvirke beslutninger, især når gruppens mandat er uklart.

- Når der er tale om et klart mandat eller manøvrefrihed viser de konkrete cases at interessegrupperne kan tage ansvar og opnå kompromisser, også i forbindelse med store konflikter.

- Potentialet for at handle i fællesskab og et stærkt engagement i medforvaltningen er endnu større inden for relativt homogene grupper som RBM-grupper med et klart afgrænset medlemskab.

- Ministerielle organer let bliver direkte involveret i sådanne konflikter, og at beslutningen om at give en formel eller uformel autoritet til interessegrupper skal overvejes grundigt.

Discard er spild af en dyrebar resurse og modvirker en genetablering af bestande på trods af lave kvoter. Fiskerisystemerne i de nordiske lande anvender en kombination af indsatser og kvotereguleringer som hovedprincipperne for at regulere fiskeriet. Indsatsreguleringen på Færøerne og discardforbuddet på Færøerne, Island og i Norge ser ud til at have været relativt succesfuldt:

- Indsatsregulering kombineret med en effektiv overvågning af fiskeriområder eliminerer kvoterelateret discard. Incitamentet til en høj fiskerieffektivitet på de fiskedage man har til rådighed kan ikke desto mindre føre til discard på baggrund af størrelse, som stadig finder sted i forbindelse med indsatsregulerende ordninger uden effektive systemer til overvågning og kontrol.

- Discardforbuddet kombineres med systemer til kontrol og håndhævelse og et lovligt mandat til indgriben når reglerne brydes.

- Discardforbuddet støttes af tekniske målesystemer med henblik på at regulere brugen af udstyr samt en regulering af fiskeperioder og fiskepladser via lukkede områder.

- Traditionen for medforvaltning og fiskernes generelle indflydelse betyder at forvaltningen af discard betragtes som rimelig og legitim af 
fiskerne, hvilket også ser ud til at have en indflydelse på graden af samarbejdsvilje.

- Discardforbuddet støttes af incitamenter til at få fiskerne til at undgå discard. Disse incitamenter består af økonomiske fordele for fiskerne ved landing af lovlig bifangst, selv om hovedparten af indtægten bruges til fiskeriforskning; åbning for fleksibilitet i forbindelse med fordelingen af kvoter med henblik på at justere fangstkvoterne; eller overdragelse af kvoter som betyder at fiskerne har ret til at købe kvoter efter landing.

Yderligere incitamenter til at få fiskerne til at undgå discard diskuteres i Danmark. Hvis fiskerne via brugen af elektroniske enheder kan dokumentere alle fangster og acceptere at de er fratrukket kvoten, så tilbydes de en mulighed for at få del i hvad der er lagt til side for discard i TACberegningerne. Vi mangler stadig at se en accept af denne nye fremgangsmåde blandt fiskere og i det politiske system.

Der er meget at lære af de nordiske lande i forbindelse med diskussionen om revisionen af den fælles fiskeripolitik. Adskillige eksempler og modeller har været fremme, men en central erfaring er at de skal udformes så de passer til den specifikke kontekst. Vi håber, at vi med denne skrivelse, er i stand til at bidrage til en omfattende diskussion af modeller og løsninger samt en diskussion af hvordan modellerne kan hjælpe med at løse problemerne i den fælles fiskeripolitik og i forvaltningen af den på både et lokalt, nationalt og regionalt niveau. 

Nordic Council of Ministers

Store Strandstræde 18

DK-1255 Copenhagen K

www.norden.org

The waters surrounding the Nordic countries are rich in fish resources. Up to this date fisheries has been among the most important productive sectors in the Nordic economies, and in the Faroe Islands and Greenland it is by far the most important sector. Management of marine fisheries has over time had various objectives in the Nordic countries, ranging from fiscal and social purposes to stock conservation and socio-economic well-being in recent years. There are strong similarities between the Nordic countries, but differences in ecosystem and the socio-cultural settings of the fisheries have lead to differentiated management systems anyhow.

The purpose of this note is to bring Nordic experience into the discussion of the reform of the Common Fisheries Policy. The discussion takes as its point of departure the socalled Green Paper in which the Commission has summarised the status of the EU fisheries and also put themes and questions up for discussion. The themes and cases of this note address issues which feature prominently in the Green Paper: reduction of over-capacity by establishing rights-based management systems, increase of the responsibility of the industry through development of co-management arrangements, and reduction of the discard of fish. 